\title{
AMYLOID DEGENERATION OF THE BRAIN IN TWO CASES OF GENERAL PARESIS.*
}

\author{
By SOLOMON C. FULLER, M. D.
}

(From the Pathological Laboratory, Westborough State Hospital, Massachusetts.)

In two recent communications (I9I I and I9I2) Mignot and Marchand ${ }^{13}$ reported certain alterations in vessels of the cerebral cortex of a general paretic and extravascular lesions of like nature, deposits of variable size in the vicinity of the affected vessels, which displaced or destroyed by pressure the surrounding nervous elements. The walls of the affected vessels were thickened, homogeneous and refractile, their lumina narrowed or obliterated. These changes, while implicating some of the larger vessels, involved chiefly capillaries and pre-capillaries. In the larger vessels the process began in the media; in the capillaries it first appeared in the adventitia. The intima, though not immune, was less frequently a starting point. This vascular tunic seemed to offer a greater resistance to the invasion, for in many instances it remained unaffected long after the other portions of the vessel wall had undergone a complete change. The physical characteristics and tinctorial reactions of the extravascular deposits were identical with the changes in the walls of vessels. The whole process was interpreted as an amyloid degeneration. More recently (I9I2) Sioli ${ }^{3}$ reported a case, also a general paretic, which presented alterations of the same character, though here not disseminated, as in the instance first mentioned, but focalized on the surface of the right tempero-sphenoidal lobe in such manner as to be mistaken at autopsy for intracranial neoplasm. Here, too, the microscopical findings were looked upon as the expression of an amyloid degeneration, or, to quote exactly, as an "amyloidähnlich Degeneration im Gehirn." These cited cases, in so far as the vascular alterations and the supposedly extravascular deposits are concerned, compare well with the few cases

* Presented in abstract at the sixty-rinth annual meeting of the American Medico-Psychological Association, Niagara Falls, Canada, June 10-13, 1913. Westborough State Hospital Papers, No. I8. 
of like nature recorded in the literature, dating from Billroth's observations in 1862 .

In the literature these changes have been described in turn as gelatinous, waxy, glassy, colloid and hyaline degeneration of the brain. They have been described even under the rather indefinite heading sclerosis (Eppinger ${ }^{8}$ ), though in this particular instance the alterations were confined chiefly to the vascular apparatus-the affected vessel walls exhibited the characteristic physical and staining properties of hyaline. Finally, as noted above, the process has been more specifically classified as amyloid degeneration, but a possible transitional or pre-stage of amyloid had been earlier suggested (Arndt," Holschwenikoff,' Alzheimer,' et al.).

The greatest number of the recorded observations have concerned cases of general paresis. Other mental conditions with which these changes have been associated are imbecility, imbecility with epileptiform convulsions (Wedl, ${ }^{\circ}$ R. Maier, ${ }^{10}$ ) psychosis undetermined but probably the mental disorder of active cerebral lues (Alzheimer ${ }^{\circ}$ ), senile dementia (Vorster ${ }^{11}$ )-though here the interpretation of the reported observation is looked upon askance* -and hydrophobia (Wasilieff," Benedikt," Kolessnikoff ${ }^{10}$ ). Similar alterations have been reported among the microscopical findings on a subject dying of a nervous disease, a case of amyotrophic lateral sclerosis (Spiller ${ }^{15}$ ). The well-described findings of Holschwenikoff' were made on a subject which, so far as known, had not suffered from any psychosis, and the nineteen cases reported by Neelsen ${ }^{20}$ were also without a history of mental disease; they were found among a group of seventy-nine brains from persons of various ages, chiefly elderly subjects.

The identity of the alterations in Holschwenikoff's case with the process under discussion, however, has been questioned (Sioli ${ }^{3}$ ), on the ground that they are better classed with the more common hyaline degeneration of arteriosclerotic vessels. As a defense for his attitude, Sioli sets forth the presence of calcareous deposits in the affected areas of Holschwenikoff's case which

* Since this paper was presented at the Niagara Falls meeting of the Association the writer has received a reprint of Ziveri's case, ${ }^{28}$ a presbophrenic with amyloid changes identical with the vascular alterations described in Case II of this paper. 
to him is prima facie evidence of their arteriosclerotic nature. Similarly, doubt has been cast on the findings of Neelsen (Alzheimer ${ }^{\circ}$ ). In Neelsen's nineteen cases conversion of vessel walls into a homogeneous substance was shown only for short stretches and this confined to the vessels of the outermost cortical lamina, most frequently at the points of branching, sometimes involving one side of the vessel, sometimes affecting it in an annular manner, but always sharply delimited. Alzheimer contended that the findings of Neelsen could not be included as examples of colloid degeneration (meaning the process under discussion), but must be considered as the hyaline change which arteriosclerotic vessels so frequently undergo. Moreover, it was pointed out that not only was the involvement greater in colloid degeneration than in ordinary hyaline degeneration of vessels, but that there were certain tinctorial differences. Alzheimer entered a plea for the use - of colloid degeneration as a designation for the process here discussed, chiefly, however, to avoid confusion with the hyaline degeneration of arteriosclerosis. Among the things which he emphasized was the albuminous nature of the deposits and the possibility that they represented a pre-stage of amyloid conversion.

Colloid degeneration has been the favorite term with which these very striking changes have been designated, but it should be stated that where this term has been employed the old $v$. Recklinghausen conception of colloid is meant. v. Recklinghausen's colloid, ${ }^{17}$ as is known, includes mucoid hyaloid and amyloid degeneration. Colloid degeneration as now understood is restricted to certain altered cellular (epithelial) secretions, such as the substance found in the acini of the thyroid gland in disease states and advancing age, the homogeneous substance of retention cysts of the kidney, casts of the urinary tubules, the similar substance encountered in some ovarian cysts, certain adrenal tumors and in many tumors of other organs.

The varieties of explanations as to the origin and chemical nature of this conversion of vessel walls into homogeneous masses and of the other homogeneous deposits which have been considered as extravascular, even surpass in number the terms employed to designate the process. Thus we find the changes interpreted as a swelling and conversion into colloid substance of the adven- 
titial and intimal cells which subsequently are welded together to form larger masses (Arndt, Schüle ${ }^{2 b}$ ); as originating from a diffuse interstitial encephalitis with an infiltration of colloid substance into the proliferated elements of the cellular glia and the proliferated cells of vessel walls (Billroth; Magnan ${ }^{20}$ ); as an albuminous degeneration of blood cells within the lumina and perivascular spaces of the affected vessels (Adler, ${ }^{20}$ Oeller ${ }^{21}$ ); as a waxy degeneration not only of the proliferated cells of the vessel wall but also of the infiltrated cells of the perivascular space (Lubimoff ${ }^{\approx}$ ); as products of post mortem origin (Wedl, Adler $\left.{ }^{*}\right)^{*}$. As the result of various dyscrasias and acute processes, also of local circulatory disturbances, particularly increased blood pressure (Holschwenikoff ${ }^{7}$ ); as albuminous deposits undergoing further chemical elaboration-a pre-stage of amyloid degeneration (Alzheimer ${ }^{2}$ ); as a deposition of hyaline substance in the walls and lumina of vessels in a telangiectic area (Beadles ${ }^{20}$ ); as a transitory stage of luetic nodular periarteritis (Witte ${ }^{\varpi}$ ) as a deposition of amyloid substance in a brain previously injured by a subacute meningo-encephalitis (Mignot and Marchand ${ }^{1}$ ); and, finally, as the terminal stage of general paretic changes, comparable to the local amyloid changes in other chronically inflamed organs (Sioli ${ }^{3}$ ).

It is probable that some of the reported observations, even some of those to which reference has been made, cannot be considered as unquestionable examples of the process here discussed, criticisms of which may be found in the cited papers of Alzheimer and Sioli, and in other contributions to the literature of this subject. It is also quite probable that processes of the same character, particularly in those instances where there has been little doubt as to being confined to blood vessels, are described under other rubrics. So appears to the writer the case reported by Witte under the title, "Ueber eine eigenartige herdförmige Gefässerkrankung bei Dementia paralytica" and Beadles' case, "A telangiectasis of the Left Frontal Lobe with Epileptiform Convulsions."

* Interesting in this connection is Stilling's interpretation of the origin of corpora amylacea, namely, as of post mortem origin, attention to which is called for reason of the possible relationship of corpora amylacea and the homogeneous deposits in the cases reported in this communication, discussed below. 
It is interesting to note that, almost universally in recent papers, attention is called to the lack of any appreciable cellular and fibrillary reactions following upon these peculiar changes which, as in the case reported by Sioli, may reach enormous proportions. Even where the process is comparatively mild, restricted and apparently of recent origin, as in Case II of the present communication, there are few tissue reactions which may not be just as well explained as resulting from other causes. This is in striking contrast to the reaction commonly observed around the focalized deposits of the split products of pathological metabolism (Abbau Produkte of the Germans), where there is often not only a rich influx of phagocytic cells (Abraumzellen) of mesodermic and glial origin, but also, depending upon the age of the process, more or less glial fibrillosis. Whatever changes are shown by the nervous elements as the result of the deposits are overwhelmingly pressure changes-atrophies and displacements, and, in consequence of these, frequently a complete disappearance of nervous structures over areas of greater or less extent.

Though mindful of the views concerning the origin of amyloid bodies from myelin sheaths and other components of nervous elements, the case of myoclonic-epilepsy reported by Lafora," Lafora and Glueck," is the only instance known to the writer where amyloid, in the form of corpora amylacea, has been found within ganglion cells.* Stürmer," in a recent defense of the glial origin of corpora amylacea in the central nervous system, prefers to consider the ganglion cell inclusions in Lafora's case as deposits resulting from cell degeneration of another nature rather than as amyloid degeneration of ganglion cells. Stürmer's objections, however, are not overconvincing, especially in view of what he lays down as a positive test for corpora amylacea, with which the structures reported by Lafora seem to comply. Looking, then, on the process discussed in this paper as an amyloid degeneration and the corpora amylacea as a form of this type of degeneration, Sioli's objections to Holschwenikoff's case, too, become less serious, if one accepts Siegert's " classification of the familiar amyloid bodies of the central nervous system into

* Mignot and Marchand, 1. c., report amyloid deposits in some of the ganglion cells in their case, but this was of the nature of the deposits in walls of affected vessels. 
corpora versicolorata and corpora flava. The latter group, according to Siegert, frequently undergoes calcification ("sie verkalken sehr haüfig"), while the former never undergoes such change ("sie verkalken nie").

These observations on the corpora amylacea are interpolated for the reason that their characteristic iodine reaction is duplicated in some of the particular homogeneous deposits of which this paper treats. One may infer from well-described cases that the chemical composition of these very striking deposits is variable, for a differential staining of them has been made (Holschwenikoff," Alzheimer," Sioli "). Moreover, it seems agreed that corpora amylacea of the central nervous system, as well as amyloid deposits of other forms elsewhere in the body, are principally nitrogenous compounds, chiefly albuminous unions of high molecular valence. So that whether or not one accepts the gliogenic, neurogenic, lymphogenic or hemogenic theories of the origin of corpora amylacea or other forms of amyloid, the suggestion of a pre-stage of amyloid degeneration for the process reported, or an amyloidähnlich degeneration, even an unqualified amyloid degeneration, may not be far of the mark.

With this sketchy presentation of some of the views concerning these peculiar changes and the principal contributions to the literature, we may pass on to the writer's personal observations on the two cases coming to autopsy at Westborough State Hospital.

\section{CASE I.}

Summary.-A bachelor of 50, formerly a lumberman in Western camps, later a bartender in frontier towns and finally, after considerable roaming about and progressively descending in the economic scale, was dishwasher in a restaurant. He had used alcohol to excess; denied lues, but admitted gonorrhœa and promiscuous sexual indulgence. For the past five years had lost his grip on things and failed in his ability to support himself as well as formerly, yet he thought he was "getting on fine." Shortly before admission he was depressed and gave utterance to certain somatic delusions-heart and pulse had ceased beating, etc. On admission, euphoric, considerable mental dilapidation ; characteristic general paretic speech disorder; contracted non-reacting 
pupils; unsteady gait, general tremor and jerky tongue. Positive Noguchi in blood serum. During hospital residence, continuously grandiose; marked memory disturbance; repeated epileptiform seizures; loss of rectal and bladder control ; terminal lobar pneumonia ; death. At autopsy, marked pial opacity, cerebral atrophy, multiple miliary gelatinous areas in cerebral cortex, granular ependymitis; lobar pneumonia; pyelonephritis, cystitis. Microscopically, the classical histopathological lesions of general paresis; numerous homogeneous deposits confined to the mesoblastic apparatus of the cerebral cortex, the marrow seldom involved, while sections from basal ganglia, pons, cerebellum and cord were free.

W. S. H., No. 9455 , an unmarried man of 50, was admitted February 27, I9II, on a transfer from Boston State Hospital (Psychopathic), where he had been a patient for four days.

Data of family history is meagre. The patient's parents were born in New Brunswick, dying at an advanced age without having suffered from mental or nervous disease. Mental and nervous diseases were denied for all other known members of the family.

Of the patient's previous history there is also little information. A brother, a fairly intelligent man, stated that when a child patient suffered an injury to the penis, the result of a burn, which explains the mutilating scar seen on the prepuce; that he had no severe illness as a child and in general was much like other boys of his community. As a youth he worked on a farm, doing good service, but on reaching his majority, some thirty years ago, he went to the Western part of the United States; since then he had not been in close touch with his relatives. Out West he worked as a lumberman in many camps and later, for several years, was a bartender in Western towns, moving about frequently. Five years ago he came East to Boston. Since he has lived in Boston he has had several places of employment, how many, neither he nor his brother can state, but each succeeding position has been lower in the economic scale than the preceding, the last as dishwasher in an ordinary city restaurant. He was of the opinion, however, that he was making progress; to use his own words he was "getting on fine." He had used alcohol freely, and judging from the shameless manner in which he related his sexual experiences, had cohabited promiscuously. Gonorrhcea several years ago; lues denied. Early in February, Igri, informant (brother), who had not seen patient for about two years, noted a marked impairment of memory; that he exhibited considerable general mental dilapidation, and, moreover, that he was despondent over the state of his health. At this time he talked a great deal of dying, saying repeatedly that his heart and pulse had stopped beating. February 23, I9I I, the patient's relatives, fearing his increasing despondency might lead to some act of self destruction, reported him to the police, whereupon he was 
sent to Boston State Hospital and four days later transferred to this hospital (W. S. H.).

In the certificate of commitment there is a statement to the effect that "he has been progressively deteriorating for some time."

The abstract from Boston State Hospital is, in part, as follows:

"Orientation.-Person, impaired. Did not know his age nor could he tell when he was born. Place, impaired. Knew this was Boston, but had no idea of suburb or general location of distance. Time, impaired. Did not know year; said February 22d, Wednesday. (Really Thursday, 23d.)

"Grasp.-Surroundings, impaired. Called this a hospital, but did not know name. Thought it was for good people. Knew position of physician, but did not of nurse. Education, impaired. Was able to read and write ......7 88 he was unable to calculate, nor could he do any but the simplest calculation, such as $2 \times 3$. In naming five cities, said St. John's, Michigan, Missouri, New Orleans, Kentucky. Could not tell who was present king of England or president of this country.

"Memory.-Remote, impaired. After leaving school, stated he worked twenty years as farmer. Then he went West, being there thirty-five years as a sawyer of lumber and saloon keeper. Cannot give any details. . . . . Recent, impaired. Thought he came here this morning. Does not remember seeing physician before, when he came this afternoon and had only recently seen the examiner. He cannot give the details of how he happened to get here.

"Hallucinations.-Denied and no evidence of any.

"Delusions.-He expresses a feeling of well being; said he was never as happy in his life; was going out to-day to work, filling a position he had recently obtained; that he was one of the best sawyers that ever was and the first to use a certain kind of saw. Thought he would like to learn how to run an automobile.

"Emotional Tone.-One of elation.

"Flow of Thought.-Nothing particular, excepting inclination to go into unnecessary detail about unimportant matters.

"Motor Phenomena.-Facial expression was one of elation. Quiet and remained in bed without trouble.

"Physical Examiration.-Contracted, non-reacting, irregularly outlined pupils; right smaller; marked speech impairment; tremors of tongue and hands; absent knee-jerks; swaying in Romberg, tremors in writing.

"Provisional Diagnosis.-General paresis."

Here.- On admission, in addition to the physical disorders noted above, ankylosis of distal articulation of right ring finger, hallux valgus (left); mutilation of prepuce from an ancient injury; recent scratch on right side of neck three inches in length; soft systolic murmur heard at apex; pulse rapid and full; firm radials; other trunk findings negative. Reads No. 2.5 D test type with right eye, No. $2 \mathrm{D}$ with left. Argyl-Robertson pupil, arci seniles. Hearing tests not satisfactory-patient not co-operating. Impairment of ability to differentiate certain common odors; hypo- 
geusia ; diminished pain sense of skin. Unsteadiness of gait, heels planted first and with force; co-ordination movements poorly executed; muscular development good; tone fair; tremor of closed eye-lids and coarse tremors of hands; patellar reflexes absent; no clonus; doubtful Babinski on each side. Speech was slow and drawling, with elision of syllables and frequent clonic repetitions of the last syllable of words. The handwriting was progressively ataxic, with syllables or words left out.

He was imperfectly oriented; thought he was in a New York hospital, but did not know what kind of a hospital. It did not disturb him to be told that he was a patient in an institution for the insane, to which he replied, "I was never better in my life. I am well mentally and physically." He was unable to give an account of the happenings in his life during the past few weeks, and the statements which he made concerning the remote past were very conflicting. He first said that he was 47 years old; later that he was 28; that he went to college for five years, entering when he was ten and leaving when twenty, but he could not give the name of the college. He was unable to perform the simplest examples in arithmetic, and his knowledge of the commonest known historical events was very defective. He talked freely of his great abilities: "I expect to make a million dollars, as I am well and hearty, I am going into the restaurant business. I have got $\$ 5000$ ahead in the Boston Bank of South Boston. It is drawing four cents a week on each dollar," etc. Notwithstanding his claims as a man "full of mental and physical possibilities," he could realize no inconsistency in this with his last employment, dishwashing. He minimized his alcoholic indulgences, said he used tobacco moderately and though he admitted gonorrhoea, he had not contracted syphilis, because he made it a point to cohabit only with married women, entering into many disgusting details. Throughout the interview he exhibited considerable elation and a marked sense of well-being.

March 28, I9II. During the past month he occasionally protested against remaining here, but generally he seemed well satisfied with his surroundings. Memory defect was the most marked mental symptom. Almost daily he made the same requests and told the same stories as though they were new. He never could tell how long here, nor give the name of his physician, the attendant or of patients with whom he conversed frequently. To-day he complained of a sensation of coldness in the right half of his body.

April 17, 1911. He was still disoriented and exhibited just as poor memory as previously noted. Though apparently duller, he insisted that he was not insane and could see no reason why he should remain here. He said he had $\$ 4000$ in bank which brought him in five cents, evidently meaning five per cent, but when his attention was called to the statement he apparently could not comprehend the difference between a deposit of $\$ 4000$ which yielded five cents and one of like sum that yielded five per cent. He had not the slightest idea of current events. Speech defect was more pronounced than at previous interviews; test phrase more poorly executed. During the last twenty-four hours he has developed an attack of diarrhœa. 
May 27, 1911. Since the last note patient has been confined almost constantly to bed, having become very unsteady on his feet and grown worse, mentally and physically. At present he is very dull, says little, not even responding to greeting of physician. He has lost in weight.

July 7, rgrr. Following the last note he was less dull and seemed stronger and was again permitted to be up and dressed. He was again euphoric, discussing freely his prowess and expectations. He usually replied to the physicians' greetings with, "Feeling fine. Get three good meals a day; nice bed to sleep in."

July 14, I911. To-day very untidy and confused; mumbles almost constantly in an unintelligible manner and attacked the attendant without apparent provocation.

August 22, 1911. In bed; very feeble; apparently clouded; speech content rarely intelligible, mutters a great deal to himself.

September 21, 1911. Very noisy, shouts and screams at the top of his voice; throws his arms wildly about and beats himself on the head, particularly the face.

September 25, 1911. A ballanitis has developed, for which surgical interference is necessary.

September 29, 191 I. Again noisy as on the twenty-first of the month; leaves bed, carrying along the bed clothing, meanwhile much confused; very tottery and falls frequently when he attempts to run around the ward.

October 4 , 1911. In two attempts to leave the bed he was so weak that he fell, each time producing severe bruises.

October 22, 19I I. Epileptiform seizure.

November 3, I9I. The patient has failed very appreciably since last note and is now constantly untidy.

November 30, 191 I. Within the last twenty-four hours he developed a severe series of epileptiform convulsions; twenty-three distinct attacks have occurred during this period.

December 25, 1911. During the past three weeks numerous epileptiform seizures have occurred. Failure has been rapidly progressive. He has been unconscious most of the time.

December 28, 1911. To-day temperature dropped to $94.2 \mathrm{~F}$. (rectal) ; previously it had been $102.6 \mathrm{~F}$. Respirations are now fifty-two per minute; bubbling râles may be heard rather generally over the lungs and there is dullness of the left lower lobe and in the region of the left axilli. Death at 10.55 p. m. Autopsy fifteen hours post mortem.

Anatomical Diagnosis.-General paresis. Increased density of calvarium, dural congestion, chronic leptomeningitis, hydrocephalus ex vacuo, cerebral atrophy, multiple miliary gelatinous areas in cerebral cortex, moderate cerebral arteriosclerosis, granular ependymitis; congestion and chronic leptomeningitis of cord; lobar pneumonia; hepatic congestion; pancreatic congestion; splenic congestion; pyelonephritis, cystitis.

Abstract of Autopsy Protocol.-The dura is congested and tense, presenting along either side of the longitudinal fissure, at the vertex, herniæ of 
Pacchionian granulations. The whole brain is congested, the pial vessels markedly engorged. The pia, besides, is very opaque and edematous. Here and there over each convexity of the cerebrum are cyst-like accumulations of fluid in the pia which have compressed the underlying gyri. Some of these areas in their greatest extent exceed the diameter of a fifty-cent piece. The pial opacity is distributed over the entire convexity, with exception of the tips of the occipital lobes, which remain relatively clear, over the mesial surfaces of the frontal lobe, the base of the cerebrum and inferior surface of pons, the base of the cerebellum and over the superior worm. The opacity is most pronounced over the frontal convexity and mesial surfaces of the frontal lobes which are welded together. The cerebral gyri exhibit some wasting, particularly those of the frontal lobes, where there is considerable gaping of sulci, and also the central convolutions, particularly their upper two-thirds. Section reveals in cortex of frontal, parietal, occipital and temporal gyri innumerable small, grayish gelatinous masses which look not unlike boiled sago, though considerably smaller, the largest scarcely exceeding in diameter that of a pin-head. Some of the granules are apparently confluent, but by far the great majority are discrete. No such alterations are found in the basal ganglia, mid-brain, pons, medulla or spinal cord. . . . . The brain with pia attached and before section weighs $1360 \mathrm{gm}$.; the skull capacity after the method of Rosanoff and Wiseman is $1620 \mathrm{cc}$.

The other gross findings noted in the anatomical diagnosis offer no special features that need to be gone into here. It might be noted, however, that nowhere in the trunk organs were gross lesions encountered which were in anyway comparable to the deposits found in the cerebral cortex. It may be added, also, that the subsequent microscopical examination of the trunk organs revealed no changes suggestive in the least of an amyloid degeneration.

Microscopic Examination.-For the reason just stated, the microscopical report is limited to the central nervous system. The typical histopathological changes of general paresis-perivascular infiltration with plasma cells, lymphocytes and other foreign cells heavily laden with lipoid granules in the pia and cortex, cortical vascular proliferation of the reticular and aggregative types, numerous rod cells, luxuriant fibrillary and cellular gliosis, destruction of ganglion cells with consequent disturbance in the cortical architecture-were abundantly shown in sections prepared after the Niss methods and Weigert's glia and elastica stains. In a greater or less degree, these changes were demonstrated by practically all other histological procedures employed in the study of this case. The typical paretic histopathology, however, was frequently overshadowed by rather numerous and extensive homogeneous deposits. The peculiar deposits were likewise exhibited by all of the technical methods, with some methods showing a great affinity for certain dyes, even with those where they failed to take the stain their optical character made them easily the most striking feature of the microscopical field. The deposits were confined almost wholly to the cere- 
bral cortex; only in areas where the involvement was the greatest were a few of them encountered in the outer portion of the white substance. Numerous sections made from the basal ganglia, mid-brain, pons, medulla and spinal cord were negative. All cortical laminæ were indiscriminately affected (Fig. I), and while generally the outer half of the gray matter contained a richer deposit, sometimes the inner half displayed the greater involvement. The mesoblastic apparatus seems to be the seat of the process, particularly the smaller vessels. In a given vessel, the deposit sometimes extended throughout all of the tunics, producing an enormous thickening of the wall and in many instances occlusion of the lumen. In those specimens where the deposits failed to take the stain, as for example Nissl sections, the affected vessel walls were of a glassy or waxy appearance, the smaller vessels looking not unlike urinary casts. Fig. I6, from Case II, serves equally well to portray the alterations in many of the smaller vessels of this case. This conversion of the vessel wall into a homogeneous substance does not take place simultaneously in all of the tunics, for frequently along with massive deposits one finds small discrete globules or groups of globules on the verge of coalescence. (Fig. 2.) Many vessels were observed in which the process was confined to a single tunic, but in such instances it was always the adventitia or media, examples of which are illustrated in Figs. 3 and 4 . In Fig. 3, a vessel found just beneath the gray matter at the bottom of a sulcus, the media is shown thickened and converted into a homogeneous mass, while the adventitia and endothelium remain relatively, if not absolutely, intact. In Fig. 4, a capillary of the molecular layer, it is the adventitia that bears the brunt of the burden. Though this vascular coat is tremendously thickened for so small a vessel, the endothelial cells are still visible and the lumen patent. Vessels so affected may go on to obliteration of the lumen and still show endothelial cells grouped about the center or nearer the periphery of the mass, depending upon whether or not the process in the vessel wall has been concentric or eccentric in its development. Finally, even endothelial cells disappear and the result as seen in section is a circular or irregular mass which may give the impression of a deposit laid down outside of the vessel wall. In Fig. 5, capillaries involved by fairly large deposits but showing their endothelium preserved, a small vessel in which the process developed eccentrically, a small occluded vessel and a comparatively large vessel presenting the typical perivascular infiltration of general paresis at the top and left of which a large homogeneous mass seems to be flowing around some of the infiltrated cells, are all shown as part of the findings in a single field of an $8 \mathrm{~mm}$. objective.

Always surrounding affected vessels, of whatever stage in the development of the process, a clear space can be made out, a space in excess of that shown around the unaffected vessels. This apparently is not the result solely of shrinkage produced by the various fixatives, but is the dilated perivascular space, brought about, in all probability, by an embarrassment of the lymph flow. 
Nowhere, in early or in advanced stages of the process, are homogeneous deposits encountered free in the dilated spaces just mentioned. That the alterations in vessel walls, with their consequent thickening and encroachment on the perivascular lymph channels, offer serious embarrassment to the lymph circulation, the appearance of tissues surrounding blood vessels of the white substance would seem to indicate, particularly in those portions of the marrow where the overlying cortex exhibited the most extensive deposits. Figs. 6 and 7 are typical of many vessels found in the white substance. In Fig. 6, peripheral to the readily visible though dilated and somewhat distorted ordinary perivascular space, is a considerably larger but wide-meshed area, its trabeculæ rather coarse fibered, not unlike the disturbances which an edema produces, save for the rather coarse fibers which traverse the lighter zone. In the perivascular space proper there is no cellular infiltration; in the meshed zone the cells shown are amoboid glia cells, large cells containing lipoid granules (probably of mesodermic origin), a few plasma cells and lymphocytes. Fig. 7 exhibits the typical perivascular infiltration of general paresis, peripheral to which is also shown an edema-like area, such as was described for the preceding figure, though containing fewer cells. When vessels so affected are stained by the tannin-silver method of Achucarro, ${ }^{20}$ sometimes the coarse-fibered mesh described above, is shown to be directly continuous with a coarse net-like proliferation of fibers in the vessel wall. Occasionally in the cortex, perhaps more frequently here than in the white substance, vessels were encountered which exhibited a coarse net-like proliferation of mesodermal fibers with an extension of the net into the surrounding structures, though never in so pronounced a manner as shown in Achucarro's published photographs. (This may in part be due to the fact that our material was not examined by the tannin-silver method until it had been conserved in formalin for about fourteen months. Nevertheless, where shown, this netlike proliferation, or syncytium of connective tissue fibers, extending into surrounding structures and in instances passing over and becoming continuous with similar adventitial proliferations in neighboring vessels, was a convincing demonstration of the type of vascular change to which Snessarew ${ }^{n} "$ and Achucarro ${ }^{\circ 0}$ have called attention. Figs. 8 and 9. Similar proliferations are also shown by the Bielschowsky method, though of course there is no real differentiation except that offered by the general appearance of the structures. Fig. 10.) In the opinion of the writer, the meshed zonal area surrounding the vessels of the white substance is not an artefact, for it has been found after all of the fixatives employed and in sections made after and without imbedding.

A careful study of those deposits described in the literature as extravascular-and indeed as such they appear from a casual inspection of Figs. 2, 5,11 and 12-leads to the conviction that in the majority of instances they are none other than greatly altered vessels, the larger masses representing enormously thickened vascular walls which have obliterated the lumina, or contiguous vessels which have coalesced. The smaller masses are con- 
ceived as fine calibered vessels whose lumina are obliterated, isolated globules or group of globules in the walls of otherwise invisible vessels and, perhaps, isolated globules in the meshes of the net-like proliferation of the adventitia which certain tannin-silver preparations strongly suggest and also indicated in Bielschowsky sections. Fig. 13. So if this latter be true (deposits in the net-like proliferation of the adventitia) then it is seen that the peculiar process involves only mesoblastic structures.

In Fig. II, a vessel is shown cut longitudinally and on either side of it rather large, irregular shaped, homogeneous masses. Such pictures suggest the relative-aggregative type of vessel proliferation described by Cerletti." The deposits shown in Fig. II, the writer believes, represent smaller vessels given off from the larger unaffected arterial twig which having undergone this homogenous change and in consequence of the shrinkage resulting from destruction of intervascular nervous elements have been brought closer together. This interpretation is not invalidated by the absence of deposits in the larger vessel which is looked upon as the main branch of this particular system, for as pointed out above-and a glance at almost any of the illustrations would show-the smallest vessels are the favored seat of these changes. Again, in Fig. 12, an aggregative type of vessel proliferation is conceivable, but here one thinks of Cerletti's absolute-aggregative type. (Figs. II and 12 were photographed under exactly the same magnification; Fig. II, frozen section of material fixed in Weigert's glia mordant, without previous formalin, and colored with Van Gieson's stain, while Fig. 12 is from a frozen section after formalin fixation, the section treated with alcohol for a few minutes and afterwards stained with Weigert's elastica stain. This latter method and the Bielschowsky silver impregnation process usually displayed the greatest number of deposits). The type of deposits which on casual inspection appears extravascular is far more numerous than the instances which offer no question as to vessel involvement.

In well-differentiated Nissl specimens the deposits are shown as glistening homogeneous masses and in those specimens sectioned without imbedding there are relatively large, clear spaces, the result of a dropping out of the homogeneous masses in the process of handling. With hæmatoxylin, such as employed in Alzheimer's method IV, or other hæmatoxylin solutions, the deposits are also glassy in appearance, while the Van Gieson method stains them in varying nuances of a dark, dull red-a brick rednever the brilliant red which connective tissue fibers of mesodermal origin take on with this stain, and makes them sufficiently distinctive so as not in anyway to be confused with glial structures. Even where the process is not sharply delimited in the wall of a given vessel, this difference in color permits a clear differentiation of the affected from the non-affected parts. (It might be noted here that material fixed in Weigert's glia mordant, sectioned without imbedding-frozen sections-and stained after the Van Gieson method yields very brilliant results, offering an excellent differentiation of the various cellular and fibrillary elements which are superior to 
the results obtained by the usual application of this method.) Carmine solutions stain the deposits a dull light red and Rosin's method a fleshpink, but none of these yield quite as many deposits as Weigert's elastica stain (applied as noted above) or the Bielschowsky silver aldehyde method, the former staining them a grayish purple to a deep royal purple, the latter in varying sepia tones to an almost pure black. The Levaditi silver impregnation method imparts a brownish yellow color to the homogeneous deposits, while Achucarro's tannin-silver produces a reddish brown color, brownish black, or black. Iodine green stains by far the great majority of the deposits a light green like most of the surrounding structures. One sees here and there, however, a mass stained a dark green and some of these latter exhibit the faintest suspicion of an amethyst or purple color tone. With methyl violet on frozen sections from formalin material the deposits, as a rule, strike a light red or pink color; some, however, are purple like the surrounding structures, while iodine solutions stain them yellow mostly, like the surrounding elements, but some of the masses are stained brown, though never a very deep brown. With sections treated from five to ten minutes with slightly acid aqueous solutions before applying the iodine, one more frequently obtained brown staining. Strong sulphuric acid being added, intensified the staining, but scarcely to the point of the classical "dark mahogany color."

Frozen sections of formalin material boiled in water, or in a strongly alkaline aqueous solution $(40 \% \mathrm{NaOH})$, were not affected in the least, so far as concerns the deposits, for after boiling and washing rapidly in water, they showed on staining with the picric-acid fuchsin mixture a great profusion of the homogeneous masses, even to the very smallest deposits. Long continued action of a concentrated acid $\left(\mathrm{H}_{2} \mathrm{SO}_{4}\right)$ did not produce a solution of the deposits, but rendered them more difficult to stain with acid fuchsin solutions and intensified the browning which some of the deposits exhibited when iodine solutions were applied.

The absence of any marked cellular or fibrillary gliosis about the deposits was particularly noticeable. To be sure, large glia cells and coarse-fibered proliferation were shown (Weigert's glia stain) about many of the vessels affected by the process, but these were not inconsistent with the glial changes of general paresis. Sometimes, where smaller deposits were grouped, coarse glia fibers could be seen threading their way through the colony and near by one or several large glia cells, but such instances were rare. Among such groups of the smaller masses, when the tannin-silver method was employed, one found occasionally a rather net-like arrangement of dark fibers (connective tissue fibers) within the meshes of which some of the deposits lay. These black fibers were well differentiated from another type of fiber sometimes seen within the groups, the brownish fibers of glial origin. In Bielschowsky sections showing fibrous adventitial nets the deposits were displayed within the meshes of the net. Fig. 13.

No ganglion cell or nerve fiber was shown which exhibited homogeneous alterations suggestive of the alterations in vessel walls. The ganglion cell 
changes observed in general paresis, of which there is an abundant literature, were practically all shown and need not be detailed here.

Finally, blocks from the frontal, central, superior parietal and calcarine areas and from the basal ganglia and spinal cord prepared after the Levaditi method proved negative for treponema pallidum.

Epicrisis.-The clinical record and anatomical findings leave little doubt as to general paresis in this case. The numerous homogeneous deposits within the mesoblastic apparatus were the most interesting of the structural changes and have given the impetus for the report of the case. The process is not a common one, though Liebmann" in an early communication maintained that it was a frequent accompaniment of general paresis, a contention not corroborated by those who have had a large experience with autopsies on this class of subjects. Indeed, since the publication of the two cases of Alzheimer in 1896 , the two cases reported in I9I I and I912, one by Mignot and Marchand and the other by Sioli, are the only instances known to the writer where the process has been recorded as present to any great degree. The alterations, then, are sufficiently rare to give a special interest to those cases in which they occur. The various interpretations which have been set forth, in the light of our increased knowledge of brain histopathology, may be now subjected to more critical analysis and, perhaps, a clearer conception of the whole process may be gained.

As to these deposits, the question uppermost is what relation do they bear to the general paretic process, or, if you will, to the underlying syphilitic infection? More and more we are recognizing a variability in the anatomical expression of lues equalling almost its numerous clinical manifestations, facts which merit scarcely more than a mere mention. In view of Noguchi's and Moore's ${ }^{3 s}$ recent discovery, we must class general paresis not as the perfect paradigm of a metaluetic process, but rather as one of the manifestations of an active syphilitic process which not only as the treponema indicates, but, as pointed out by these observers, is also indicated in the commonly present Wassermann reaction. Amyloid degeneration of trunk organs as associated with the infectious granulomata is not an extraordinarily rare finding at autopsy, though more common in the material from a general hospital than among the autopsies on the insane. That similar deposits did not occur in the trunk organs is interesting, but points, 
perhaps, to the fact that the infection played itself out largely in the central nervous system. In a way, then, the deposits described above may be looked upon as one of the many structural changes which accompany or result from a syphilitic infection, to be sure while not as common as some other changes may occur as frequently, let us say, as some of the rarer endothelial alterations of small cortical vessels described by Nissl. ${ }^{25}$ The characteristic microchemical reaction of amyloid, however, was certainly lacking in by far the great majority of the deposits, and yet the manner in which some of them responded to iodine solutions and iodine green was at least suggestive of a transitional stage of amyloid. Moreover, the richer deposits which some methods showed over others, with material from areas not over a few millimeters apart and sometimes from the same block, together with certain differential staining of the deposits in almost any given section would indicate a difference in their finer chemical composition. Bearing in mind what was mentioned above, as to amyloid substances being albuminous unions of high molecular valence, one may interpret the deposits in this case as a sort of pre-stage of amyloid.*

The more detailed study of the homogeneous masses in this case does not lead one to look upon them as degenerations in the common acceptation of the term as applied to fixed cells or even to proliferated cells originating in the vicinity or coming from a distance, in so far as cells of epiblastic origin are concerned. In the hundreds of sections examined, not a single cell or fiber of the glia or nervous apparatus exhibited the slightest suggestion of a deposit comparable to the alterations shown in vessel walls. The origin of the deposits, therefore, must be sought in the mesoblastic apparatus and its circulating fluids. To consider these homogeneous masses as resulting from albuminous precipitates from the blood plasma or lymph is not wholly speculative; it is at least worthy of consideration. Always, as shown by the illustrations, it is mesodermal fibers that undergo this homogeneous conversion and the more or less round, small, light areas sometimes seen in the deposits (for example Fig. 6) may be residuals of mesoblastic cells

* Concerning the vast literature of the origin of amyloid no review can be undertaken here. The reader is referred to the recent paper by Stürmer ${ }^{*}$ on corpora amylacea and to Weigert's ${ }^{*}$ critique on coagulation necrosis and its relation to hyaline formation. 
in the perivascular infiltration and proliferated cells of the vessel walls. As an interpretation of the zonal disturbance about the vessels of the white substance as illustrated in Figs. 6, 7, and 9, the writer conceives nothing more satisfactory than to look upon it as the result of a lymph transudation seeking a point of least resistance, or perhaps a simple dilatation of the perivascular space, its natural course being impeded by the enormous deposits in the vessels of the overlying cortex.

A feature which the study of this case brings out is the existence of many more blood vessels of smaller caliber than were supposed to be present in the brain, assuming of course that the submitted interpretation of the so-called extravascular deposits (vide Microscopical Examination) is correct. Cerletti, ${ }^{2}$ in his recent monograph on vessel proliferation, has called attention in rather convincing manner to what we have been in the habit of considering as vascular proliferations in certain chronic wasting diseases of the brain as no actual increase in vessels but only vessels which have always existed, now occupying a smaller area as the result of the destruction of intervascular elements. Even in certain acute processes he has shown that many vessels are brought to light by alterations in their walls which otherwise would have escaped notice by present technical procedures. The findings in this case, the writer believes, substantiate the views of Cerletti as to relative vessel proliferation. If those at first sight, seemingly-extravascular deposits, are not residuals of vessels, or deposits within the proliferated net-like extensions of the adventitia, then their presence is difficult to explain. As to deposits within the proliferated extensions of the adventitia, Fig. I3 seems to give conclusive evidence.

\section{CASE II.}

Summary.-A woman of 26 , with history of hysterical behavior and unconventional social conduct, when 24 and during a period of stress as result of family misfortune and financial stringency, had a convulsive seizure-right hemiplegia supervening, but lasting only a few hours. Six months later, sudden loss of consciousness with convulsions and frothing at the mouth, for several days thereafter much confused mentally. Then followed a period of considerable sexual hyperæsthesia and after about four months 
apparent apoplectic insult with right hemiplegia and motor (!) aphasia for four days. Marked mental dilapidation ensued. Three months later another apparent apoplectic insult, also followed by loss of motor power in right lower extremity with partial restoration later, but general physical weakness and mental deterioration progressed ; she was depressed and hallucinated. In hospital, more or less permanent aphasic disorder, for the greater part of the time untidy and mentally confused. Sudden development of motor weakness in right leg and right arm with wrist drop and pseudo-athetoid movements of right hand, lasting over a month, and then almost as suddenly restitution of power and normal manipulations of hand. Cutaneous pain sense persistently diminished; Noguchi blood serum test positive. Finally, a wild delirium; lobar pneumonia ; death. At autopsy, gross lesions of general paresis, no coarse focal lesions of brain. Microscopically, typical histopathology of general paresis, lesions indistinguishable from active cerebral lues and focalized amyloid changes of vessels in right calcarine area.

W. S. H., No. 10058, a woman of 26 , was admitted March 30, 1911, with a history of mental disorder of five months duration, though it is likely, judging from the anamnesis, the disturbance had existed for a longer period. This was her first admission to a hospital of this character.

Family History (as given by husband).-Father and mother are living and in good health, the former 70 , the latter 55 years of age. Three sisters and two brothers are living and well. A third brother is a heavy drinker. A fourth brother was formerly at the Waverly School for Feebleminded (Mass.). He is said to have had an accident when a small child, following which he developed epileptic convulsions. He has since died. One of the sisters is a wayward girl, having given birth to an illegitimate child when fourteen.

Previous History.-(There were two sources of information regarding the past history of patient-each more or less hostile to the other-a sister and the husband. The sister claimed that the husband was only a common law husband, and that his ill-treatment was mainly responsible for patient's present condition, while the husband maintained that family interference and constant nagging of relatives had brought about her predicament. So that many statements from each of these sources had to be taken cum grano salis.)

As given by sister: Up to patient's fifteenth year nothing out of the ordinary run of a young girl's life is reported. When she was fifteen, she ran away with a youth of about her own age and was married to him, but the union was not a happy one and two years later she secured a divorce 
on the ground of non-support. She then went to live in Boston, having previously lived in a small New England town, supporting herself as a waitress. This she did for two years, when in the course of her duties she met the present husband, with whom she has lived ever since, but was never formally married to him. It is claimed that the man failed to support her properly; that she was obliged frequently to do outside work, working in a laundry and at other forms of hard labor to obtain the necessities of life. Of hardships with her husband she said nothing to her family until the summer of I9II, when she was on a visit to her people. At that time, the sister states, she appeared much run-down physically and mentally, she was discouraged and very unhappy. She refused, however, to leave her husband and make her home with her parents as they had requested. During the visit home, while out in the garden one day, she had some sort of seizure, she fell unconscious to the ground and was convulsed. The sister did not remember whether or not the convulsions were of a general nature, but said that patient frothed at the mouth and that for two days following she was very much confused. Shortly afterwards she returned to her home in Cambridge and is said to have had a violent quarrel with her husband and his relatives, but she did not leave him. In January, 1912, she was still weak and in consequence could not aid in support of the household as formerly, but she received little sympathy from her husband. It is said the husband was jealous and abusive of her. Soon after the episode in January she made several attempts to leave her husband, in fact actually left his roof, but each time returned voluntarily.

As given by the husband, the previous history reads something as follows: Since husband has known patient she has always been "excitable, strong tempered and very impatient," especially "when not allowed her own way," easily becoming "hysterical," yet withal readily calmed when reasoned with. Save for a rather obstinate constipation, her health, on the whole, had been good. For about a year, 1907-1908, she increased rapidly in weight, weighing $180 \mathrm{lbs}$., whereas her normal weight was about $130 \mathrm{lbs}$., but was not as well as formerly. This was due, the husband believed, to an inactive mode of living and to constipation which was most severe during that period. After 1908 she was much more active, lived in Panama for six months, rode horseback considerably and adopted a diet containing much raw fruit, with resulting loss in weight and general improvement in health. For two years she was in good health. During the latter part of 1910 she was impelled from family considerations to take into her home a younger sister, who at the age of fourteen was about to give birth to an illegitimate child. The sister's misfortune was a source of much worry to her and this, coupled with her husband's financial affairs, which made it difficult for them to pay their bills with regularity, seemed to completely overwhelm her. At this time (December Io, I910,) she is said to have had " a very slight attack of paralysis, which lasted only a few hours." In October, I9II, one day while the husband was away from home, she had some sort of fit, called, it is said, by the attending physician " an attack of 
epilepsy," and that this was followed by a paralysis of the right half of the body and a marked impairment of speech. (From the rather poor description given, the speech defect was probably a motor disorder.) The paralysis and the speech disturbance lasted in full force for three or four days and then gradually improved, but the improvement in speech lagged behind the restoration of motor power. Even after the improvement in speech and paralysis she was more or less forgetful and generally indifferent. On the date of the last-mentioned attack she had been sorely disappointed in having to forego attendance at the Brockton Fair. In January, 1912, she had another fit, also followed by right hemiplegia, which lasted about three days. This attack supervened a long automobile ride which had been not only fatiguing, but also depressing, in that while at her mother's home to which they had driven she had been much commiserated, the mother and a sister expressing their fears to her that she (patient) was "going into decline." For several weeks prior to this last attack she had exhibited considerable sexual hyperæsthesia but now this abated; her memory was worse and she failed progressively. At this time, because of her husband's business (insurance agent) and without a maid and other companionship, she had to be left alone most of the daytime. She then began to seek companionship by visiting the neighbors in the apartment house where she lived to whom she was not welcome and on such visits managed to get into several quarrels. All of this contributed to make her condition worse. Finally, for several weeks at a time she would not leave her bed, refused to have the bed linen changed, would not eat, claimed she could hear her mother who lived at a distance talking to her; lost in weight, became depressed and said she would not live.

Herc.-On admission a young woman of slender build, though well proportioned and relatively well nourished, presented the appearance of considerable personal neglect. As she met the receiving physician she seemed perplexed and apprehensive and was rather resistive. She refused to walk to the ward and had to be wheeled. The character of the gait on entrance, therefore, could not be determined, but a later observation did not show any special alteration, save perhaps an extreme care in taking each step, a certain lack of surefootedness.

The heart's action was of good force and normal tempo, no murmurs, blood pressure $119 \mathrm{~mm}$. $\mathrm{Hg}$. Nares obstructed; high arched palate; respirations vesicular; no ràles; no dullness. The tongue was heavily coated, the buccal cavity dry ; examination of abdominal viscera revealed no pathological conditions. The breasts were pendulous; the skin in fair condition, save for numerous small abrasions on face, the result of constant picking, numerous small, dark moles on torso and vaccination scars on arms; dermographia.

The pupils were widely dilated and reacted sluggishly to light and accommodation; hearing in right ear apparently normal, in left ear greatly impaired. Tests for taste and smell integrity or impairment gave doubtful results. She did not react to rather deep pin pricks of the skin, even over 
the nipple areas. The soles of the feet, however, were very sensitive to stroking. She did not co-operate in tests for the discrimination of cold and warm stimuli; swaying in Romberg. All tendon reflexes elicited; no Babinski; no Oppenheim; tremor and jerkiness of tongue ; coarse tremor of outstretched fingers; co-ordination movements poorly executed.

She smiled almost constantly and this, with the widely dilated pupils, gave a rather animated facial expression. She smacked her lips frequently as though there were something in her mouth which she relished. To most questions she replied, "I don't know," or, "Not acquainted," and these expressions she uttered rather indistinctly. Other replies were frequently wholly unintelligible. She understood simple requests and usually complied with them, such as, put out your tongue, hold out your hands, spread the fingers, etc. She gave correctly her own name, the name of her husband and her home address. To all other questions as to orientation and for determination of the possible existence of hallucinations or delusions, she replied as noted above, "I don't know," " not acquainted." She permitted her tongue to be repeatedly pricked with a pin without showing the slightest objection or the least discomfort. She exhibited a sense of modesty in that she took great pains not to expose any part of her person save when requested to do so for an examination. In general she appeared to comprehend what was said to her, despite the character of her replies. Spontaneous speech utterances were few and reactive sentences were usually short and generally paraphasic or altogether unintelligible.

April 2, 1912. Last night, the third after admission, patient was much disturbed; she was not only noisy, but walked about the ward aimlessly and tried to get into the beds of other patients. A warm pack was given with beneficial results.

April 8, 1912. During the last three days patient has been very quiet; she has been untidy much of the time. She lies in bed with eyelids partially closed, apparently taking no notice of her surroundings. She makes no effort to assist herself. Once since admission she has shown a tendency to resistiveness.

May 7, 1912. During the last month patient's appetite has been poor; she had to be tube-fed sixty-three times in April and four times since the beginning of May. She has lost in weight. She lies in bed with her head beneath the bed clothing. When spoken to she usually smiles in a rather silly manner and either says nothing or mumbles unintelligibly. Moreover, she takes no interest in her surrounding and does not co-operate with examiner, so that orientation, delusions or hallucinations cannot be determined. She does not appear hallucinated.

July 18, 1912. To-day patient began to have convulsive movements of the right extremities, but when sharply spoken to by the nurse the movements ceased suddenly.

July 22, 1912. Constant twitching of muscles of right shoulder and arm, especially of the trapezius. The shoulder is jerked upward and the head downward and to the right. She is conscious, but her replies to questions 
are no better than previously noted. The pupils are widely dilated and very sluggish to light. The nurse reports that the twitchings began in the muscles of the lower arm and hand, and that for about half an hour the thumb and index finger moved rapidly. No Babinski; no Oppenheim.

July 24, 1912. The muscular contractions recorded in the last note, particularly those of the right trapezius, continued actively until to-day; now they are barely perceptible.

August 27, 1912. Early in present month she began to reply to questions rather more frequently and in a more orderly manner than formerly, but she was still untidy with bladder and bowel movements. She also ate better for a while, but since the $22 \mathrm{~d}$ of the month has been tube-fed. Today in reply to the physician's greeting she said she was "feeling well" and volunteered the remark that her husband was here lately (fact) and added that she preferred to remain at the institution rather than return to her home. After this she would answer no further questions or make any voluntary remark; only smiled in a silly manner.

October 31, 1912. Since September 13th, when she began to eat of her own accord, she has seemed brighter mentally, but her speech content is of ten paraphasic. To-day the pupils are widely dilated and stiff to light, and there is considerable jerkiness and tremor of the tongue on protrusion. There is also considerable motor weakness of the right arm and hand. The right hand is reflexed at the wrist, while the fingers are extended. With this hand she makes apparently involuntary movements which are athetoid in character. When she attempts to walk the gait is rather tottery and somewhat ataxic (!).

Co-operation in the aphasic examination undertaken was poor, with consequently unsatisfactory results. She appeared, however, to comprehend simple language and complied with simple requests. She made no attempt to carry out more complex tests. Her greatest difficulty seemed an inability to find the proper word or words with which to form her replies.

$Q$. What is your name?

A. W-. (Correct.)

$Q$. What is your name?

$A$. Esther W (Patient's first name is Jeannette.)

$Q$. How old are you?

$A$. I am (then after a long pause and rather hesitatingly) about 30 . Is that good? I guess it's old enough.

$Q$. How long have you been sick?

$A$. Not very long.

$Q$. How long have you been sick?

$A$. (No answer.)

Etc. No answer to questions to determine orientation of parts of body. Asked to count from I-IOO, she got as far as 39 , but with great difficulty, giving hesitatingly each number and remarking frequently, "I know just as 
well." From 40-50 she had to be prompted several times. She could go no farther. When shown a watch, coin, pencil, keys, scissors, etc., and asked to name them, she invariably replied, "I ought to know." Asked to tell the time of day by the watch, she repeated the question. Asked to repeat the words of the hymn America said, "My Country, ties of thee-Sweet lavender," and then made no further attempt.

November 4, 1912. Cutaneous pain sense again tested. She does not react to pin pricks anywhere, even where deep enough to draw blood. The pupils are dilated and still; she failed to co-operate in tests for accommodation. The knee-jerks are exaggerated, right more than left. The condition of the right hand remains as described above. Attempts to straighten the hand seem to cause the patient pain, for she winces and draws it away. The tongue comes out straight, but is tremulous and jerky. She named correctly a bunch of keys and a pencil, but failed to name a watch and several other common objects. Where do you live? W-_. (Patient's name.) What is your name? A lowly uttered, unintelligible reply. To all other questions she was silent, only smiled at the questioner. Her facial expression denotes a fair degree of elation. The nurse reports that at times she talks of past events in her life, of her early life and of happenings on the ward during her stay here; that some days she talks better, that is, practically without paraphasia, and also that she frequently gives the impression of wanting to say something but cannot find the proper words to express herself.

November II, 1912. To-day she straightened her right hand voluntarily the first time since the peculiar wrist drop and pseudoathetoid movements developed and manipulated the hand in a normal manner, though rather falteringly. Since the last note it has been observed that the pupils vary greatly from time to time in their diameter, but all light reaction fail.

January 2, 1913. Following the last note patient began to show some mental improvement: she displayed more interest in her surroundings; became more tidy; even asked to be taken to the toilet and generally complied with requests. The quality of spoken language improved and while she could only occasionally name correctly a series of objects placed before her, spontaneous speech utterances were better. The pseudoathetoid movements of the right hand disappeared and she made some effort to use the hand which she had previously favored. She could grasp rather large objects, take up a piece of bread and feed herself with this hand when anyone stood by ; otherwise she fed herself with the left hand.

A week ago she suddenly became wildly excited and acted as though hallucinated. She screamed aloud, threw herself from the bed and attempted to run about the ward, but the weakness of the lower extremities, particularly the right, caused her to fall frequently. She appeared terrified yesterday while in the neutral bath and fainted. After removal an examination of the lungs revealed some moist râles, but no areas of consolidation.

January 3, 19r3. A Noguchi test of the blood serum gave a positive re- 
action. Patient continues wildly excited, especially when anyone enters her room.

January 8, 1913. Two days ago a temperature of $102 \mathrm{~F}$. (rectal) developed. Examination revealed a consolidation of the right lung. Since the onset of the temperature she has been less excited. The mouth is dry and sordes collect rapidly on the teeth and tongue. Three days ago she repeatedly frequently the word "ray," the only intelligible word uttered since the excitement, and whenever the examiner said the word she smiled. Yesterday she said "dry" and pointed to her mouth. When water was given she seemed very grateful. These two words are the only intelligible utterances since the onset of excitement. She has emaciated. The pulse is weak and rapid and there is difficulty in swallowing.

January II, 1913. Patient continued to fail and died at II.50 p. m.

Anatomical Diagnosis.-General paresis. Increased thickness and density of calvarium, dural congestion, pial congestion and opacity with pronounced increase Pacchionian granulations, atrophy of cerebral gyri, granular ependymitis, few atheromatous patches of the larger vessels at the base of cerebrum, no coarse focal lesions save area in right calcarine cortex extending for a distance of approximately $2.5 \mathrm{~cm}$. and involving area of the line of Genarri which is grayish in color, glistening, firmer and more elevated than surrounding structures of the cut surface (amyloid degen, gumma!), congestion and pial opacity of spinal cord; moderate chronic aortitis of ascending aorta; lobar pneumonia; hepatic congestion; splenic congestion; gastritis; pyelo-nephritis, cystitis, uterine congestion, cystic ovaries .

Abstract of Autopsy Protocol.-The calvarium is of variable thickness, measuring through perpendicular portion of frontal bone $1.2 \mathrm{~cm}$., through portions of the parietals and occipital $\mathrm{I} \mathrm{cm}$., its diplo scant. The dura is normally adherent, congested and bulges laterally. The visceral surface of this membrane is smooth. The pia is congested, edematous and opaque. The opacity is limited largely to the cerebral convexity (frontal and parietal areas), the mesial surfaces of the frontal lobes and the superior surface of the cerebellum. Pacchionian granulations are greatly increased, appearing along middle two-fourths of the longitudinal sinus on each side in one continuous line and extending downward on the convexity at some points for distances of fully $1.5 \mathrm{~cm}$. Over the foot of $F_{1}$ and also $F_{2}$ (right side) are several small more or less circular areas (3-5 mm.) in diameter, where the pia is considerably thickened, rough and firm. These areas look not unlike Pacchionian granulations. More orally similar areas are found, some of which overlay and extend into the sulci. The cerebral gyri exhitit considerable atrophy which, though diffused throughout the cerebrum, is most pronounced in the frontal regions and generally throughout the left hemisphere. There is accordingly a moderate degree of cerebral asymetry, the right hemisphere being the larger. On the left occipital convexity, a semilunar sulcus (Affenspalte) presents and on the right side there is a similar sulcus, but this is interrupted inferiorly by an annectant gyrus. 
Otherwise there is no material variation from the usual cerebral configuration. Save for a few small atheromatous patches in the basal artery and middle cerebrals, the blood vessels offer no gross changes. The pons, medulla and cerebellum share in the general atrophic changes. The floor of the fourth ventricle presents a granular appearance, as though sprinkled with sand, and on section of the cerebral hemispheres the ependyma of the lateral ventricles present a similar condition though less marked. The gray matter, rather generally, is thinner than normal and the cut surface is everywhere congested. Coarse focal lesions fail, save in the calcarine cortex of the right hemisphere, where a distinctly noticeable grayish, firm linear area involving the line of Gennari and immediately contiguous portions seen in sections of the upper lip of the fissure in a space not exceeding much more than $2.5 \mathrm{~cm} . . .$.

The brain with pia attached and before section weighs $1040 \mathrm{gm}$. After section, the right hemispheres weigh $480 \mathrm{gm}$.; the left $450 \mathrm{gm}$.; pons, medulla and cerebellum $180 \mathrm{gm}$. The skull capacity after the method of Rosanoff and Wiseman is $1200 \mathrm{cc}$. Representative levels of the spinal cord on section reveal no gross tract alterations. . . . .

The subject had emaciated greatly and a lobar pneumonia in the gray stage of hepatization, a cystitis and pyelo-nephritis were found, but these need not be detailed. The only other gross finding to which attention would be called was the position of the right hand. This was much as described in the clinical history (vide supra), save that while the proximal and middle phalanges were extended, as above, the distal phalanges were slightly flexed, so that the hand had something of the appearance of the socalled " claw hand."

The trunk organs offered no gross or microscopical evidence of amyloid degeneration.

Microscopic Examination.-The microscopical report is limited to the central nervous system, for much the same reason as was given in the report of Case I.

Here, the classical histopathology of general paresis predominated. Nevertheless, certain areas in the occipital cortex-where to be sure paretic lesions are commonly less severe-in the lenticular nuclei and even in the central gyri were less typical of paresis. One encountered a perivascular infiltration, largely or exclusively lymphocytic, and certain endothelial proliferations, usually in small vessels without infiltrative phenomena, which made one think of a "lues-general paresis combination," or a transition of more acute luetic changes into the more chronically coursing paretic histopathology. Attention was arrested immediately by vessels so affected, for the infiltration exceeded by far the most pronounced infiltration of the plasma cell type, and these latter were by no means insignificant while those vessels which exhibited a proliferation of succulent-looking endothelial cells were equally striking. The infiltrative type of lesion was found alike in gray and white substances, while the endothelial proliferative type was exhibited only in the cortex. The pial infiltration, however, 
was always sharply delimited from the underlying cortex, even in the small focalized areas of great thickening and opacity noted on the convexity of the frontal lobes.

While none of the areas studied were wholly free from one or more of the typical histopathological features of general paresis, sections from some areas if taken alone would not warrant an anatomical diagnosis of paresis. Yet the case cannot be considered as an example of Lissauer's paralysis, even though certain clinical symptoms previously detailed might suggest such a possibility. In Fig. I4, a twenty $\mu$ section from the right calcarine cortex-alcohol fixation, celloidin imbedding, Van Gieson stainif one disregards for the moment the rather prominent focalized area or apparent vessel proliferation with marked alterations in the vascular tunics, there is little suggestive of paresis. There is certainly no very appreciable stratigraphic disturbance, so common in paresis; no perivascular infiltration visible at this magnification; no "packets" or other evidence of increased vessel proliferation, either side of the previous excluded zone. Yet, in this section, infiltration of small vessels with a few plasma cells, and rod cells can be found with the oil immersion objective. Compare with Fig. I5, a fifteen $\mu$ section $T_{1}$, left, technical details as in Fig. 14, save for staining with toluidin blue after Nissl, and one has less hesitancy in pronouncing general paresis.

Little, if anything, would be gained by a more detailed description of the paretic changes shown in this case, but before going on with the consideration of more special changes a word should be added of the spinal cord. In the spinal cord there were no system lesions sufficiently pronounced as to be demonstrable as such in myelin sheath preparations, but with the Alzheimer IV and V methods, particularly V, a somewhat richer fiber net work and an increased number of fiber-forming glia cells were shown in the pos-terior columns and pyramidal tracts. With all methods employed a great number of corpora amylacea were encountered, most numerous in the posterior columns. They exceeded by far the number of such structures so commonly shown in spinal cord sections from elderly subjects.

For the writer, the most interesting of the microscopical findings were the alterations in the walls of vessels found in the short stretch of the calcarine cortex noted in the autopsy protocol, alterations stratigraphically focalized in the area corresponding to Brodmann's $I V c, V, V I a$ and $V I b$ laminæ. Fig. I4 gives a good representation of the focal character of the process and of the wealth of vessels displayed in the affected area. Whatever the nature of the process may be there is little doubt of its intimate relation to the vascular apparatus and that it is restricted chiefly, if not wholly, thereto. So-called extravascular deposits are not evident at this magnification, as for example in Fig. I from Case I. In the section of which Fig. 14 is a photograph (Van Gieson stain, alcohol fixation) the most of these altered vessels are stained a dark dull red, the remainder varying nuances of red, but in well differentiated toludin specimens, as in Fig. 16 (celloidin removed before staining), they are colorless and highly refractile. (In 
poorly differentiated toludin sections they are stained in all shades from a very deep blue to an azure and if the celloidin is not removed they are always a very dark blue.) Many of the affected vessels seem entirely occluded by the process and in such all tunics seemed to have suffered equally. The deposits are laid down as discrete globules which may be seen in varying sizes in vessels where the process is less advanced. These globules tend to coalesce, but even in the vessels most affected and where there is apparent occlusion, evidence of their independent origin is still shown. (Figs. 17 and 18.) Sometimes a vessel is shown in the wall of which none but very fine globules are displayed, but these fine globules are readily detected and differentiated from other structures by their highly refractile property in toludin specimens and in sections of the Alzheimer IV method, their great affinity for the fuchsin of the Van Gieson stain, and the blue color with the Alzheimer V. Sections from material fixed in Weigert's glia mordant, cut on the freezing microtome, or after rapid dehydration, paraffin imbedding and then stained after Van Gieson proved most instructive. Fig. 17 is the photograph of a section prepared as last mentioned. To the right a vessel is shown longitudinally in which all sizes of the globules are displayed, while at the left and superiorly are occluded vessels with coarser deposits. By this method, too, affected vessels are shown in the disturbed area which are stained yellow, though such staining is not as common as the dark red and lighter red. With iodine green few vessels show a distinct amethyst color and with iodine solutions an equal number are stained a rich brown. Cellular and fibrillary glia reactions, as Figs. I6 and 17 show, are not especially marked in the vicinity of the affected vessels, though one occasionally sees in a section as pictured in Fig. 18 a large glia cell attempting to inclose a globular deposit which, however, is so near, or a part of a vessel that it is not clear whether or not the presence of this cell has relation to the vessel as a diseased vessel, or is a special reaction to the deposit. With the Levaditi silver impregnation method for treponema pallidum, while some of the altered vessels take the silver in varying shades of brown, the greater number preserve their natural color, a glistening waxy appearance. The search for treponema, as in Case I, proved negative. Here, however, there was considerable fibrillary glia impregnation, which made the search much more difficult.

Epicrisis.-The clinical record of Case II, if taken in its entirety, might possibly justify a diagnosis of general paresis, especially when one considers how protean this mental disorder may sometimes prove, but it is certainly not a typical history. Among the gross and microscopical alterations, however, paretic lesions predominate and, despite the presence of certain histopathological features to which attention has been called, anatomically therefore there is little warrant for anything else but a diagnosis of general paresis. 
In the beginning of the patient's hospital residence hysteria was given some consideration, influenced largely by data obtained from one source of the previous history. Hysteria, however, was soon abandoned for an organic psychosis, a psychosis dependent upon one or more coarse focal lesions, or perhaps a radiating focus, but in either case a lesion of luetic origin. The speech disorder, the right-sided motor weakness, the deformity of the right hand associated with pseudo-athetoid movements, together with the positive Noguchi in the blood serum, had suggested this. The apoplectiform type of seizure with restricted motor residuals, while not unknown in general paresis, is far less common than the seizure of the epileptiform type, with resulting paresis more diffuse in character. The comparative rarity of the former type of seizure was perhaps the main factor in the staff conference decision for either an endothelial type of cerebral lues or a gumma. Indeed, anatomically there was some slight justification for such a view, but evidence for general paresis was greater. Of course, the possibility of a "lues general paresis combination" comes up for consideration, but if general paresis is a luetic and not a metaluetic condition, as at present seems very likely, the changes which this case exhibited would mean simply that we have in the same brain two types of luetic lesions, comparable in a way to the combined inflammatory and non-inflammatory form of cerebral lues described by Nissl.

The vascular alterations in the short stretch of the calcarine area of this case supplement the more extensive alterations found in Case I. Despite the limited area involved, more conclusive evidence of a transitional stage of amyloid degeneration was shown, in that some of the altered vessels gave positive microchemical reactions for amyloid-yellow staining with the Van Gieson procedure, amethyst with iodine green, and dark brown with iodine solutions.

As regards cerebral vascularization, here, too, the question of actual vessel proliferation arises. In view of what was said above with regard to a relative vascular increase and that some vessels are visible by present methods only after certain changes have taken place in their walls, it is possible that the great wealth of vessels displayed in the affected area of Fig. 14 may be more apparent than real, in so far as actual proliferation is concerned. 
General Summary and Conclusions.

The process described above has been long known, as the cited references attest. Under different captions, cases exhibiting the self-same process, in varying stages of development, are recorded, and some of these cases are described in detail. One is surprised, therefore, at the assertion of Mignot and Marchand that they believed theirs to be the first case of amyloid degeneration of the brain reported.

Everyone who has familiarized himself with the literature on vascular alterations of the brain knows that the homogeneous changes which the walls of cerebral vessels frequently undergo may be widely distributed and the vessels involved intensively; that differentiating features concerning such changes have been established. All homogeneous alterations of vessel walls are not of the same character, whether as viewed from the standpoint of physical properties, staining reactions or etiological factors. It has not been the object of this paper to show up such well-known facts; rather its purpose has been to determine, on the basis of our present knowledge of brain histopathology and by approved technical methods, just how much one may claim on structural grounds as a reasonable interpretation of these peculiar deposits, in the literature of which cases dying of general paralysis have furnished the greatest number of exemplars.

Two cases of general paralysis of the insane, one with a rather typical clinical course, the other presenting symptoms apparently of focal origin which obscured the clinical diagnosis, showed at autopsy, in addition to the usual gross anatomical changes of paresis, the typical histopathological lesions of the disease. In one case (Case II) there were added certain proliferations of the cells of vessel walls, indistinguishable from histopathological lesions of the endarteritic non-paretic type of cerebral lues. Other alterations present in both cases were certain glistening, grayish or "fish-flesh" appearing, homogeneous deposits, visible to the unaided eye and limited chiefly to the cerebral cortex. In Case I they were small, for the most part discrete, thickly sown in the frontal and parietal areas and found in other portions of the cortex. In Case II this type of alteration was restricted to a portion of the right calcarine area. Here, however, the macroscopic appearance was that of a confluent mass. Microscopically, 
the process was shown to have involved the mesoblastic apparatus by the deposition of stuffs in the walls of blood vessels which eventually converted them into structureless masses. Many of the apparently extravascular deposits proved to be only residuals of vessels, the lumina of which had become obliterated, or groups of vessels which had coalesced as the space between them had become annihilated by the encroachments of their respectively thickened walls, while the remainder not so classed could be reasonably interpreted as deposits within the meshes of the adventitial net-like proliferations exhibited by many vessels. Moreover, the process brought to light a richer vascularization than is usually shown in the most pronounced type of the atrophic paretic cortex. The study of this rich vascularization in a general way confirmed the contentions of Cerletti, namely, that what heretofore has been looked upon as actual vessel proliferation in the brain, in the majority of instances, is more apparent than real. The microchemical differences which these deposits exhibited led one to conclude that, despite the wide distribution in Case I and the extent to which surrounding structures had been compromised, the process was still in a stage of devolution, with an amyloid degeneration as the goal. The tannin-silver method in demonstrating the connective tissue invasion of nervous structures by a net-like extension of the proliferated adventitia of blood vessels added not only confirmation of the previous observations of Snessarew and Achucarro, but furnished the final link in the chain of evidence that in these two cases the process played itself out in the mesoblastic apparatus.

\section{REFERENCES.}

I. Mignot, R. and Marchland, L.: Mode de développement de le dégénérescence amyloïde dans le cerveau. Compt. rendu de la Soc. Biol. de Paris, Tom I, pp. 989-991. I9I I.

2. - Paralysie générale avec dégénérescence amyloỉde du cerveau et syndromé psuedo-bulbaire. L'Encéphale, Vol. VII, p. 497. 1912.

3. Sioli, F.: Ueber amyloidähnliche Degeneration im Gehirn. Zeitschr. f. d. g. Neurol. u. Psych., Bd. 12, pp. 447-464. 1912.

4. Billroth, T.: Ueber eine eigenthümliche gelatinöse Degeneration der Kleinhirnrinde, nebst einigen Bemerkungen der Gefässerkrankungen zur chronischen Encephalitis. Archiv der Heilkunde, Bd. 3, pp. $47-62$. 1862 . 
5. Eppinger, H.: Mittheilungen aus dem pathologisch-anatomischen Institut zu Prag. 3. Eigenthümliche Sklerose der Gehirngefässe. Vierteljahrschr. f. d. prakt. Heilkunde, pp. 50-68. 1875 .

6. Arndt, R.: Eine eigenthümliche Entartung der Hirngefässe. Virchows Archiv, Bd. 4I, pp. 46I-469. 1867.

7. Holschwenikoff: Ueber hyaline Degeneration der Hirngefässe. Virchows Archiv, Bd. I12, pp. 552-568. 1888.

8. Alzheimer, A.: Die Colloidentartung des Gehirns. Archiv f. Psych., Bd. 30, pp. 18-51. 1898 .

9. Wedl, C.: Histologische Unterzuchungen über Hirntheile dreier Salzburger Idioten. Wiener med. Jahrbücher, I9 Jahrgang, pp. I39I42. 1863.

10. Maier, R.: Pathologisch-anatomische Notizen. Festschr. Freiburg i. Br., 1867. Cited by Alzheimer 8 .

Ir. Vorster: Ein Fall isolierter Hyalinbildung im Stirnhirn. Allgem. Zeitschr. f. Psych., Bd. 52, p. 1138 , Abstract. 1896.

12. Wassilieff, N.: Ueber die Veränderungen des Gehirns und der Herzganglien bei der Lyssa. Centralbl. f. d. med. Wiss., I4 Jahrgang, pp. $625-627.1876$.

13. Benedikt: Cited by Holschwenikoff 7.

14. Kolessnikoff, N.: Pathologische Veränderungen im Nervensystem bei der Wuthkrankheit. Centralbl. f. d. med. Wiss. I3 Jahrgang, pp. 853-654 1875 .

15. Spiller, W. G.: Amyloid, Colloid, Hyaloid and Granular Bodies in the Central Nervous System. N. Y. Med. Jour., Vol. LXVIII, pp. 217219. 1898.

16. Neelsen, F.: Ueber eine eigenthümliche Degeneration der Hirncapillaren. Archiv d. Heilkunde, Bd. 17, pp. I19-133. 1876.

17. v. Recklinghausen: Allgem. Pathologie Bd. II. Stuttgart. I883.

18. Schüle, H.: Sectionsergebnisse bei Geisteskranken nebst Krankheitsgeschichten und Epikrisen, p. 192. Leipzig. 1874

19. Magnan, M.: De la dégénérescence du cerveau dans la paralysie générale. Arch de physiologie norm. et pathologique. Tom II, pp. 251-262. 1869 .

20. Adler: Ueber einige pathologische Veränderungen im Gehirne Geisteskranker. Archiv. f. Psych., Bd. 5, pp. 346-378. 1875.

21. Oeller, J. N.: Ueber hyaline Gefässdegeneration als Ursache einer Amblyopia Santurnina. Virchows Archiv, Bd. 86, pp. 329-359. I881.

22. Lubimoff, A.: Beiträge zur pathologischen Anatomie der allgemeinen progressiven Paralyse und Mittheilungen über eine besondere colloidartige Degeneration der Hirngefässe. Archiv f. Psych, Bd. 4, pp. 579-599. 1873 .

23. Stilling, B.: Neue Untersuchungen über den Bau des Rückenmarkes, p. 47. Cassel. 1859 .

24. Beadles, C. F.: A Telangiectasis of the Left Frontal Lobe, with Epileptiform Convulsions. Mott's Archives of Neurol., Vol. I, pp. 440452. 1899 . 
25. Witte, F.: Ueber eine eigenartige herdförmige Gefässerkrankung bei Dementia paralytica. Zeitschr. f. d. g. Neurol. u. Psych., Bd. 2, pp. 675-682. 1910.

26. Lafora, G. R.: Ueber das Vorkommen amyloider Körperchen in Innern der Ganglienzellen; zugleich ein Beitrag zum Studium der amyloiden Substanz in Nervensystem. Virchows Archiv, Bd. 205, pp. 295-303. 1911. See also, On the Presence of Amyloid Bodies in the Protoplasm of the Ganglion Cells; a Contribution to the Study of the Amyloid Substance in the Nervous System. Bull. No. 3, Govt. Hospital for Insane. Washington, I911.

27. Lafora, G. R. and Glueck, B.: Contribution to the Histopathology and Pathogenesis of Myoclonic-Epilepsy. Bull. No. 3, Govt. Hospital for Insane, pp. 96-108. Washington, 1911.

28. Stürmer, R.: Die "Corpora Amylacea" des Zentralnervensystems. Nissls u. Alzheimers Arbt., Bd. 5, pp. 417-518. 1913.

29. Siegert, F.: Untersuchungen ueber die Corpora amylacea sive amyloidea. Virschows Archiv, Bd. 129, pp. 513-546. I892.

30. Achúcarro, N.: Darstellung von neugebildeten Fasern des Gefässbindegewebes in der Hirnrinde eines Falles progressiven Paralyse, durch eine neue Tannin-Silbermethode. Zeitschr. f. d. g. Neurol. u. Psych, Bd. 7, pp. 375-383. 191 I.

31. Snessaraw, P.: Ein Fall atypischen progressiven Paralyse der Irren mit Entwicklung von Fibrillennetzen des Bindegewebes in der Hirnsubstanz. Neurol. Centralbl. 30 Jahrgang, pp. 590-599. I9II.

32. - Ueber die Modifizierung der Bielschowskyschen Silbermethode zwecks Darstellung von Bindegewebsfibrillennetzen. Zur Frage des Stromas verschiedenen Organe. Anatom. Anz., Bd. 36, pp. 40I-4II. I9IO.

33. Cerletti, U.: Die Gefässvermehrung im Zentralnervensystem. Nissls u. Alzheimers Arbt., Bd. 4, pp. I-168. 1910.

34. Liebman, V.: Zur pathologischen Histologie der Hirnrinde der Irren. Jahrbücher f. Psych., Bd. 5, pp. 230-242. 1884.

35. Noguchi, H. and Moore, J. W.: A Demonstration of Treponema pallidum in the Brain in Cases of General Paralysis. Jour. Exp. Med., Vol. XVII, pp. 232-238. 1913.

36. Nissl, F.: Diskussion über das Referat Plaut-Alzheimer. Allgem. Zeitschr. f. Psych., Bd. 66, pp. 924-929. 1900.

37. Weigert, C.: Kritische und ergänzende Bemerkungen zur Lehre von der Coagulationsnekrose mit besonderer Berücksichtigung der Hyalinbildung und der Umprägung geronner Massen. I885. Gesammelte Abhandl. Carl Weigert, Herausgegeben von R. Rieder, Bd. 2, pp. 167-187. Berlin. 1906.

38. Ziveri, A.: Su di un caso di demenza presbiofrenica. Riv. di Patologia nerv. e ment. Anno XVIII, fasc. 5. 1913. 


\title{
EXPLANATION OF PLATES.*
}

\author{
Figures i-I3 are from Case I, i4-i8 from Case II.
}

FIG. 1.-Bielschowsky's method. The homogeneous deposits are shown in all cortical laminæ but sharply delimited from the white substance Zeiss $a^{*}$, no oc., bellows $292.5 \mathrm{~cm}$.

PIG. 2.-Frozen section fron material fixed in Weigert's glia mordant $V$ an Gieson's staining. Homogeneous deposits involving considerable portions of vessel wall, small globular masses and even finely granular deposits in the same vessel; numerous occluded vessels, singly and in groups which have coalesced, surrounded by relatively large clear spaces; no appreciable cellular or fibrillary gliosis. Zeiss $8 \mathrm{~mm}$. apochromat, comp. oc. No. 4, bellows $125 \mathrm{~cm}$.

FIG. 3.-Bielschowsky's method. The media of a small artery is shown converted into a homogeneous mass, the adventitia and intima unaffected apparently. Zeiss $2 \mathrm{~mm}$. apochromat, no oc., bellows $100 \mathrm{~cm}$.

FiG. 4-Van Gieson's stain. Small vessel in molecular layer of cortex, left paracentral lobule. Somewhat eccentric development of the process, adventitia involved, endothelial cells still visible, lumen patent. Zeiss $8 \mathrm{~mm}$. apochromat, comp. oc. No. 4, bellows $165 \mathrm{~cm}$.

Fic. 5.-Van Gieson's stain on material as in Fig. 2. Typical perivascular infiltration of G. P., occluded and partially occluded vessels, one of the deposits, as it were, flowing around and between the plasma cell infiltrate. Zeiss $8 \mathrm{~mm}$. apochromat, comp. oc. No. 4, bellows $125 \mathrm{~cm}$.

Figs. 6 and 7.-Histological technics as in preceding figure. Vessels of white substance surrounded by an edema-like area, in Fig. 6, scant infiltration, in Fig. 7, typical G. P. infiltrate, dilated perivascular space traversed by fibers of connective (mesoblastic) tissue proliferation. Zeiss $8 \mathrm{~mm}$. apochromat, comp. oc. No. 4, bellows $67.5 \mathrm{~cm}$.

Fic. 8.-Achucarro's tannin-silver method. Net-like proliferations of the adventitia which invade the surrounding nervous structures and anastamose with similar proliferations in nearby vessels. Zeiss $8 \mathrm{~mm}$. apochromat comp. oc. No. 4 , bellows $67.5 \mathrm{~cm}$.

Fig. 9.-Technics and photographic details as in Fig. 8 , but here the vessed photographed is from the white substance and corresponds in location and type of alteration to the vessel pictured in Fig. 6.

FIG. 10.-Bielschowsky's method, section of cortex. The fibrillary proliferations surrounding the vessel here shown are interpreted as principally of mesoblastic origin. Though this method does not differentiate as the tannin-silver procedure, careful study convinces one of their direct continuation with at least some of the fibers in the vessel wall; no deposits within the meshes of the fibers. Zeiss $8 \mathrm{~mm}$. apochromat, comp. oc. No. 4 , bellows $80 \mathrm{~cm}$.

* All figures in reproduction from original photomicrographs have been reduced one-third. 
Fig. 11.-Van Gieson's stain. The homogeneous masses either side the vessel sectioned longitudinally are interpreted as the altered branches given off from the central uninvolved vessel. Zeiss $8 \mathrm{~mm}$. apochromat, comp. oc. No. 4 , bellows $67.5 \mathrm{~cm}$.

FIG. 12.-Frozen section from material fixed in formalin, section treated with alcohol for ten minutes, then stained with Weigert's elastica stain. Here innumerable, apparently extravascular deposits, interpreted, however, as vascular, are shown, for the most part discrete, but confluent masses still showing the independent character of the globules composing them are also exhibited. Photographic details as in Fig. II.

Fig. 13.-Histological technics and photographic details as in Fig. 10. Here, however, in what is conceived as a mesoblastic connective tissue proliferation proceeding from the vessel seen slightly above the center of the photograph, small homogeneous masses are shown within the meshes of the net-like proliferation.

Fig. 14.-Van Gieson's stain on material fixed in alcohol, celloidin imbedding. The section from right calcarine area shows the focal disposition of the process in Case II and the apparent great increase of vessels within the affected area. Zeiss AA, no oc., bellows $170 \mathrm{~cm}$.

Fig. 15.-First temporal, left, toluidin blue after Nissl to show the paretic changes and to compare with Fig. I4 from the same case. Note the perivascular infiltration and the disturbance in the third lamina. Zeiss A $\Lambda$, no oc., bellows $187.5 \mathrm{~cm}$.

Frg. 16.-Toluidin after Nissl from a section including a portion of the focalized area shown in Fig. 14. Note the glistening, somewhat waxy, appearance of the altered vessels, which look not unlike urinary casts, and the absence of any appreciable cellular gliosis.

Figs. 17 and 18.-Van Gieson's stain on material fixed in Weigert's glia mordant from the focalized area in right calcarine area. In the longitudinally coursing vessel at the right (Fig. 17) the deposits are shown in varying sizes, the lumen still patent, while the vessels shown above and slightly to the left are occluded and the deposits are in larger masses. In Fig. I8 a large glia cell is shown, apparently in the act of engulfing one of the deposits. Both photographs are from the same section. Photographic details as in Fig. II. 
AMERICAN JOURNAL OF INSANITY, VoI. LXX, No. $4 . \quad$ PLATE II.

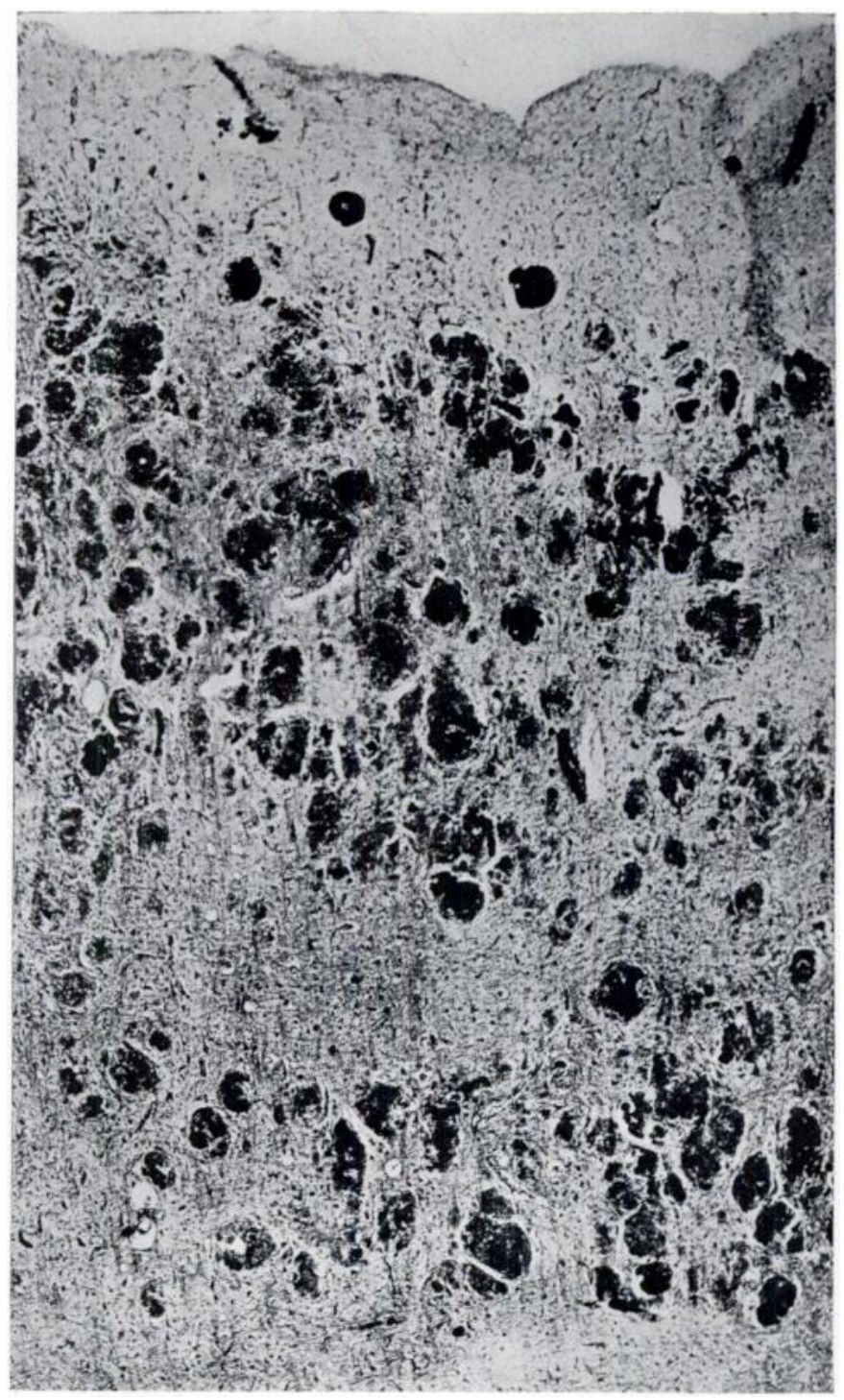

Fig. I. 
AMERICAN JOURNAL OF INSANITY, VoI. LXX, No. $4 . \quad$ PLATE III.

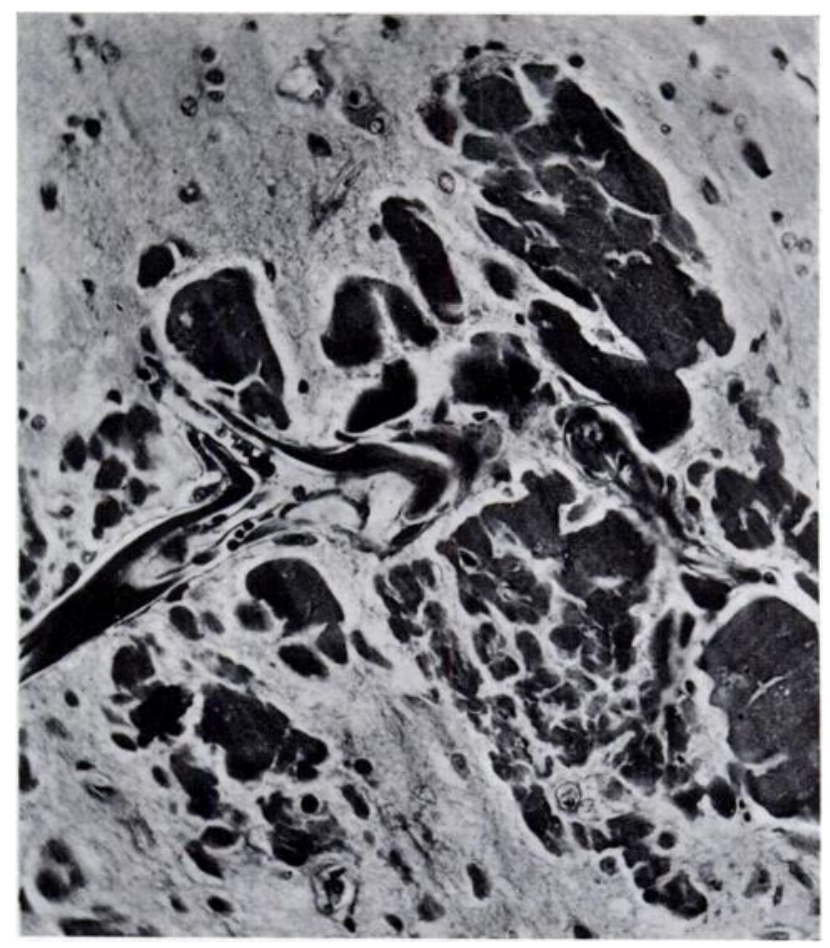

Fig. 2.

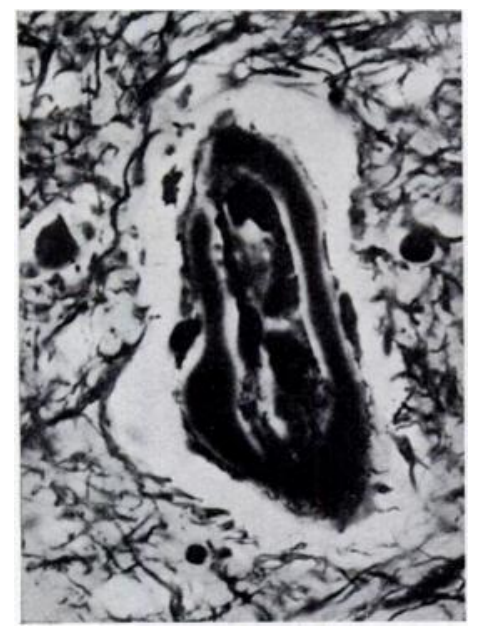

FIG. 3.

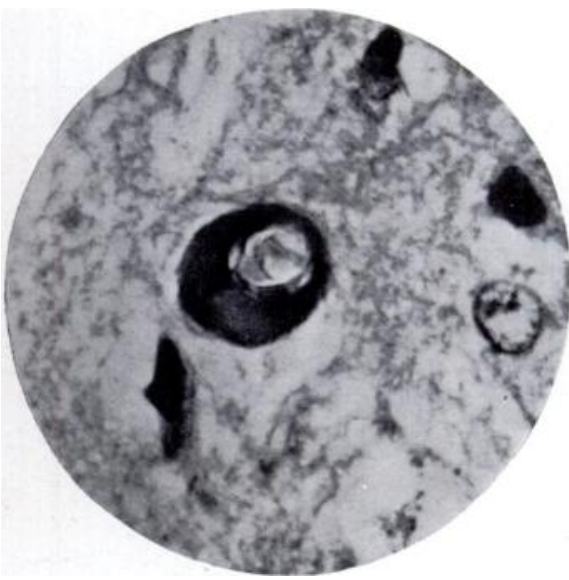

FIG. 4. 


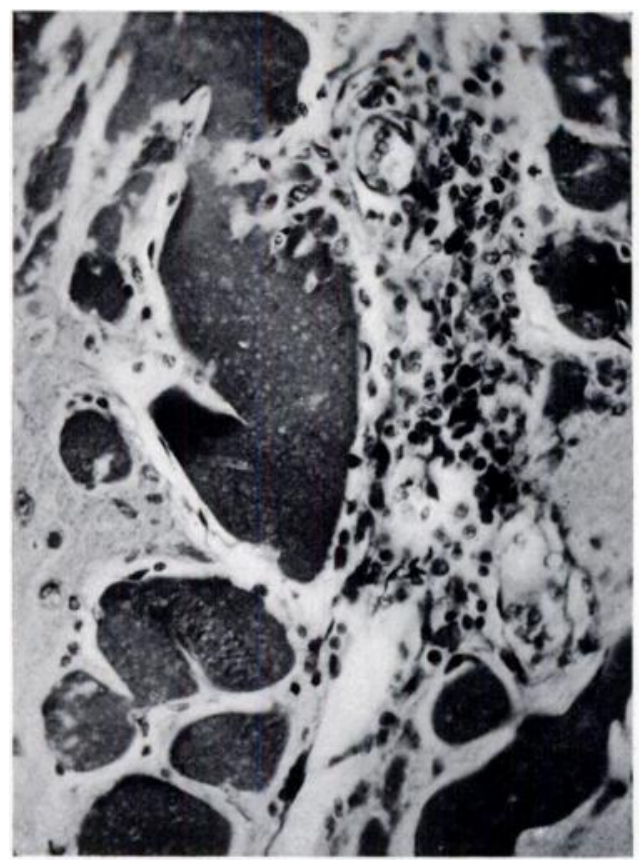

FIG. 5.

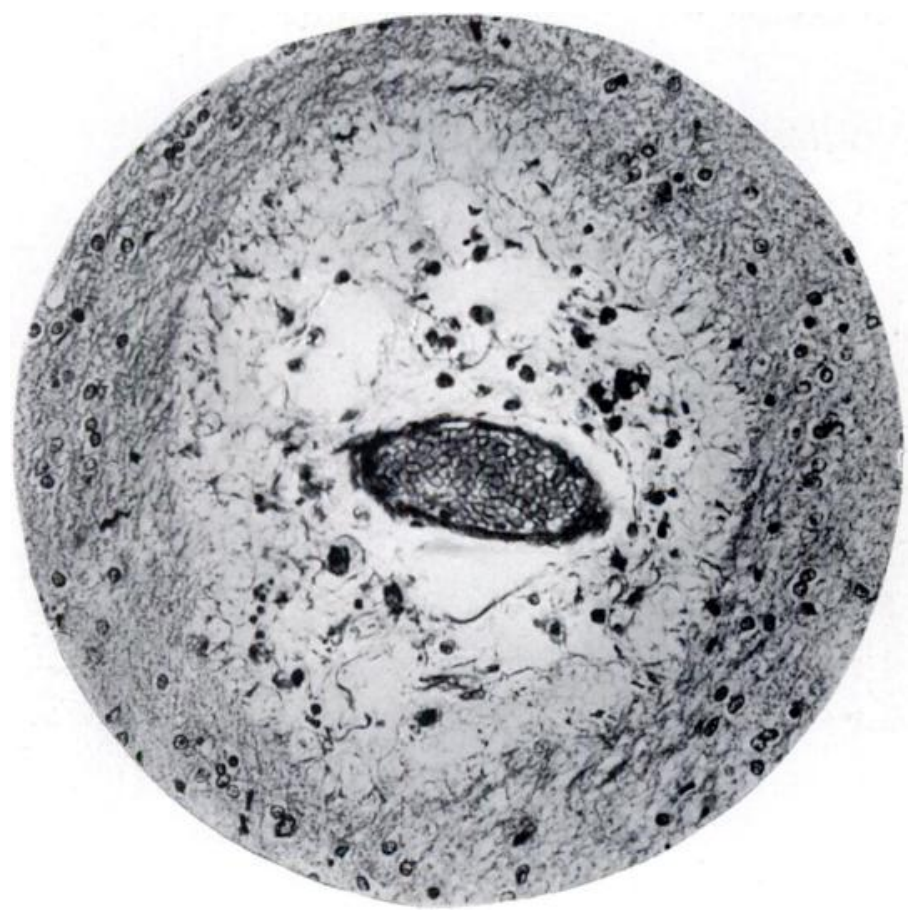

Fig. 6. 

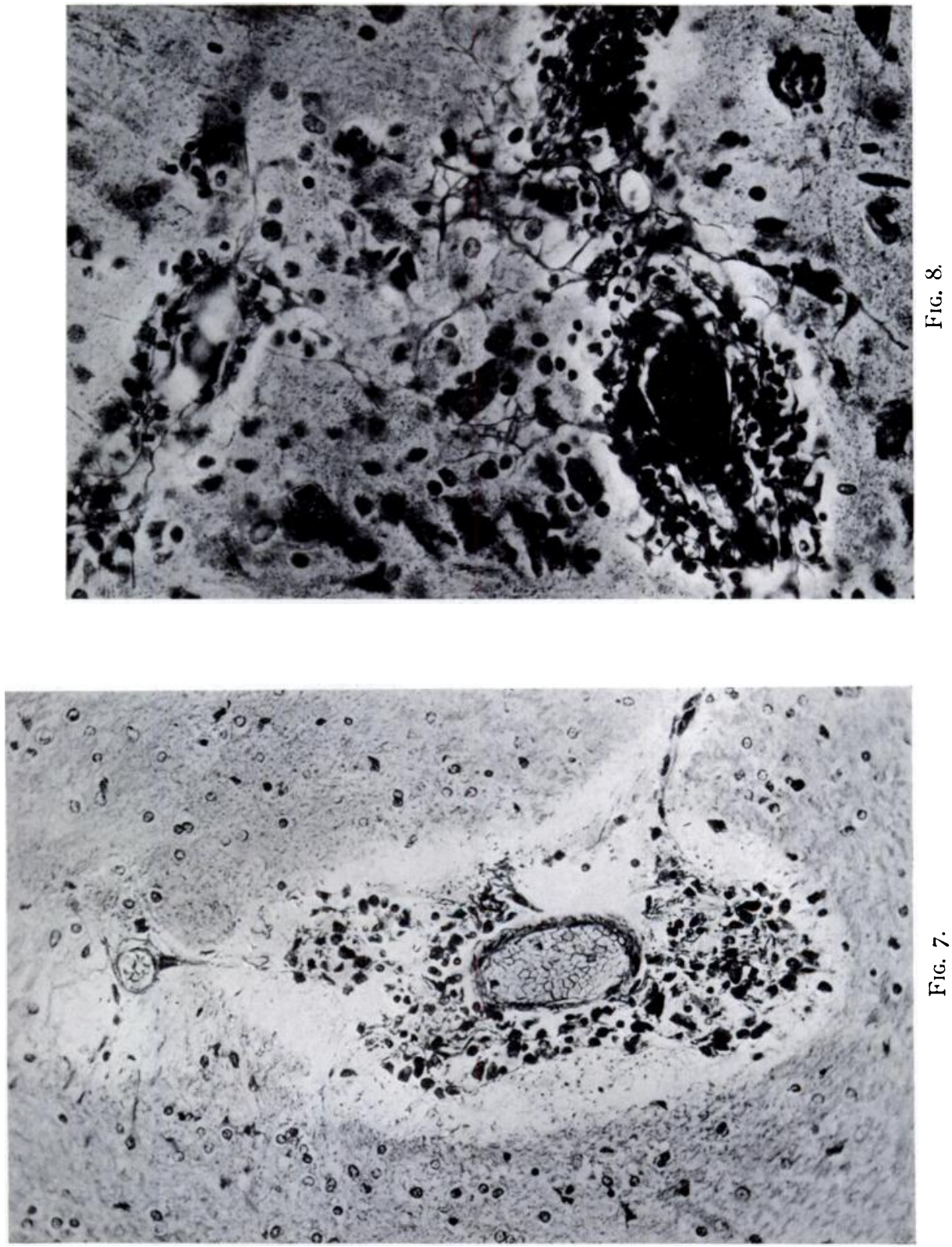


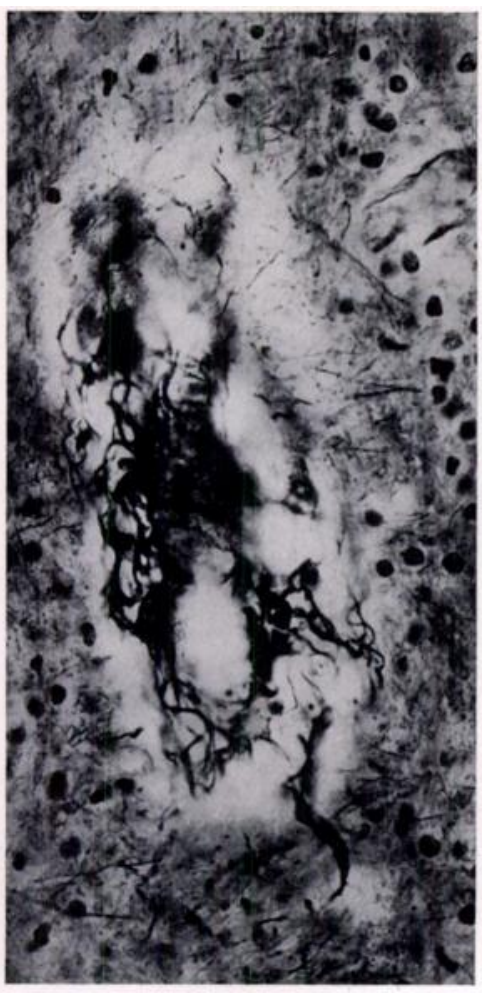

FIG. 9.

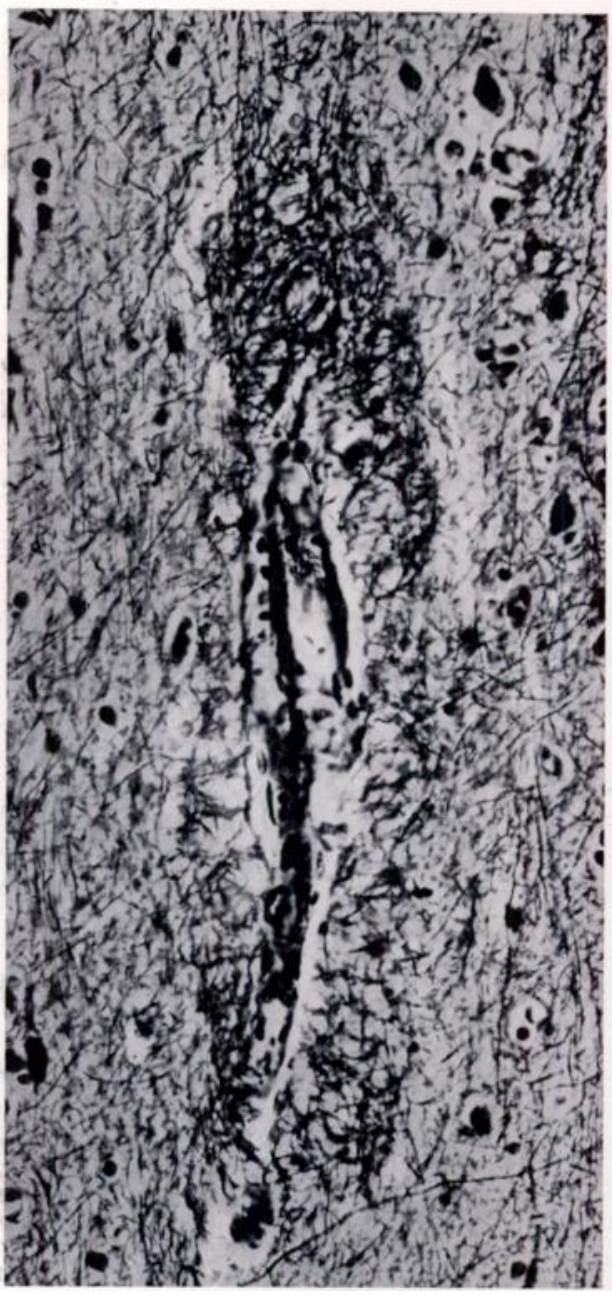

FIG. Io. 
AMERICAN JOURNAL OF INSANITY, VoI. LXX, No. $4 . \quad$ PLATE VII.

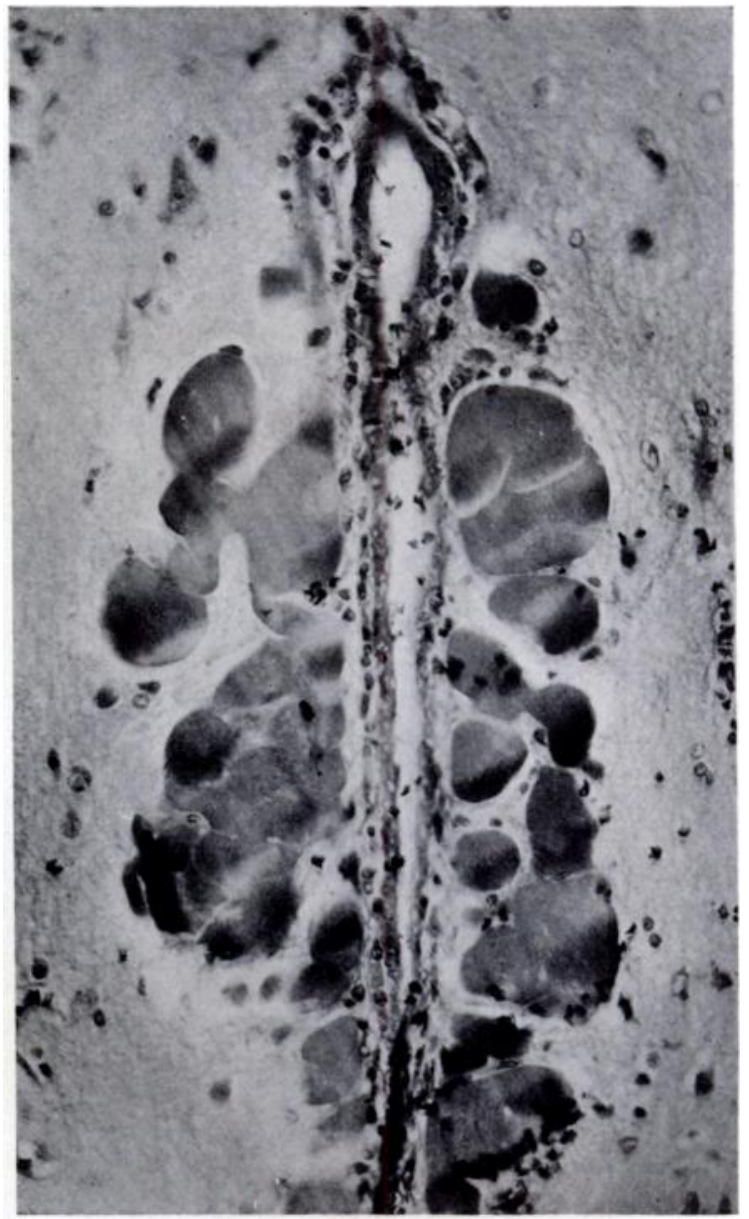

FIG. II. 

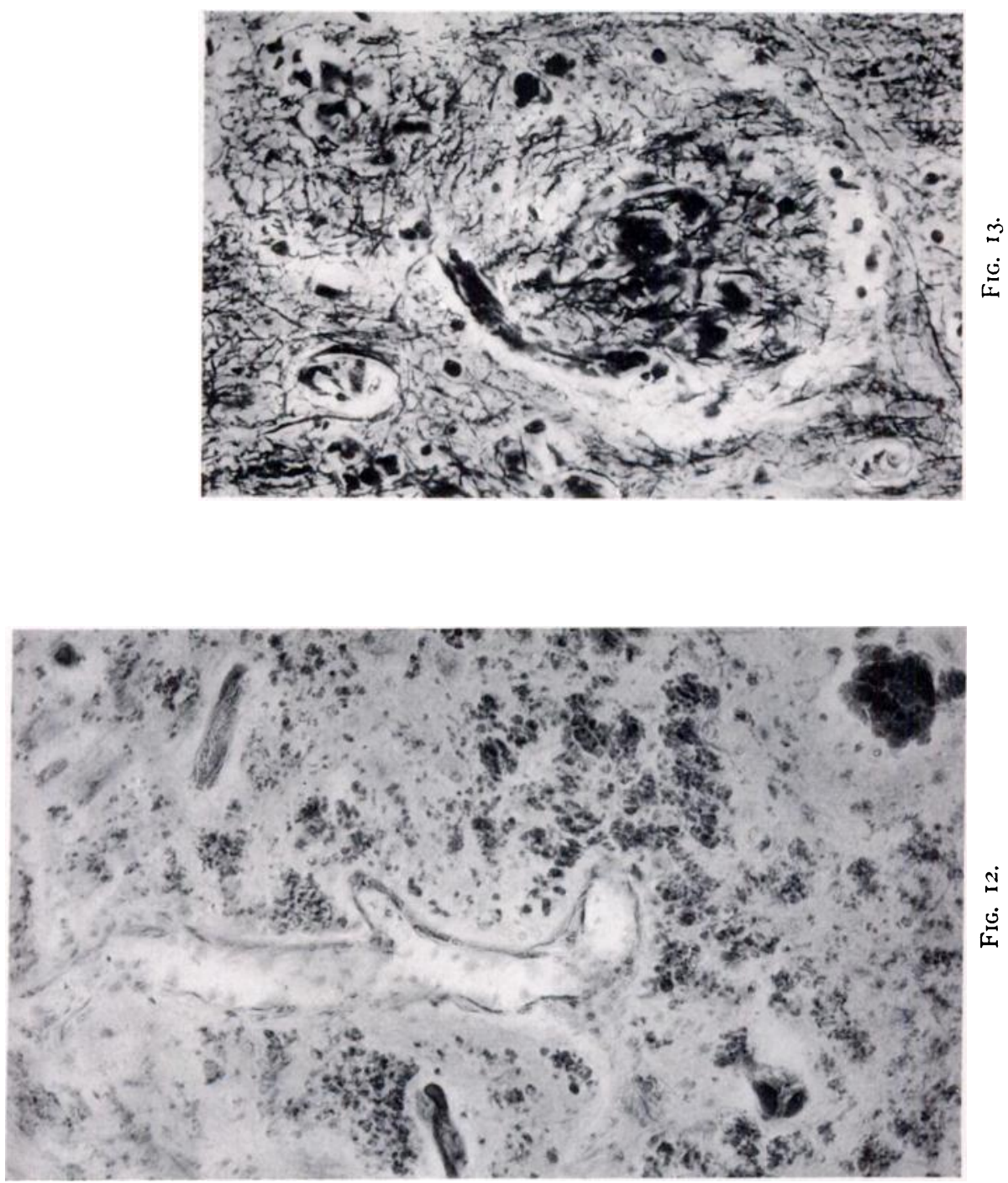
AMERICAN JOURNAL OF INSANITY, Vol. LXX, No. 4. PLATE IX.

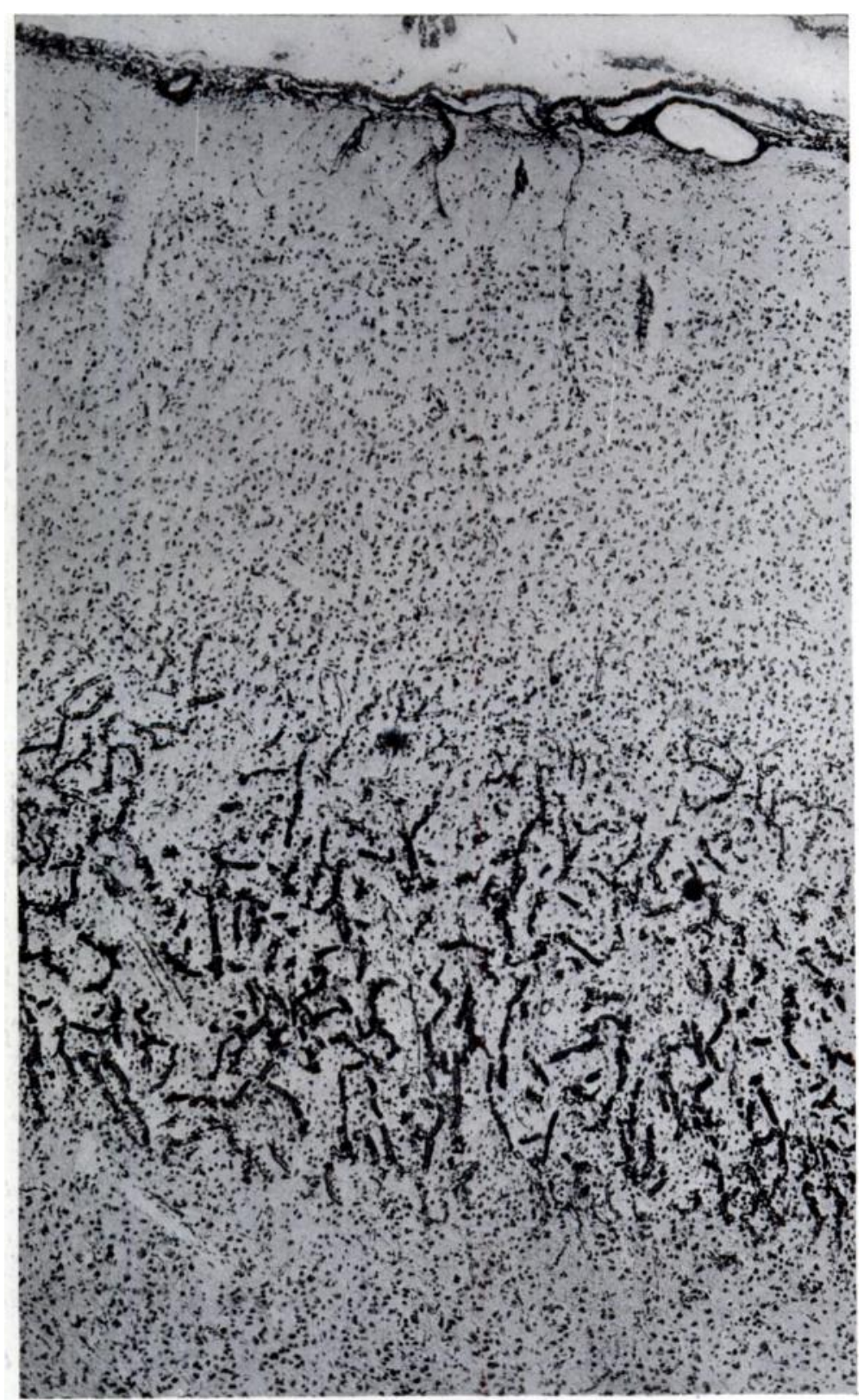

Fig. 14. 
AMERICAN JOURNAL OF INSANITY, VOI. LXX, No. $4 . \quad$ PLATE X.

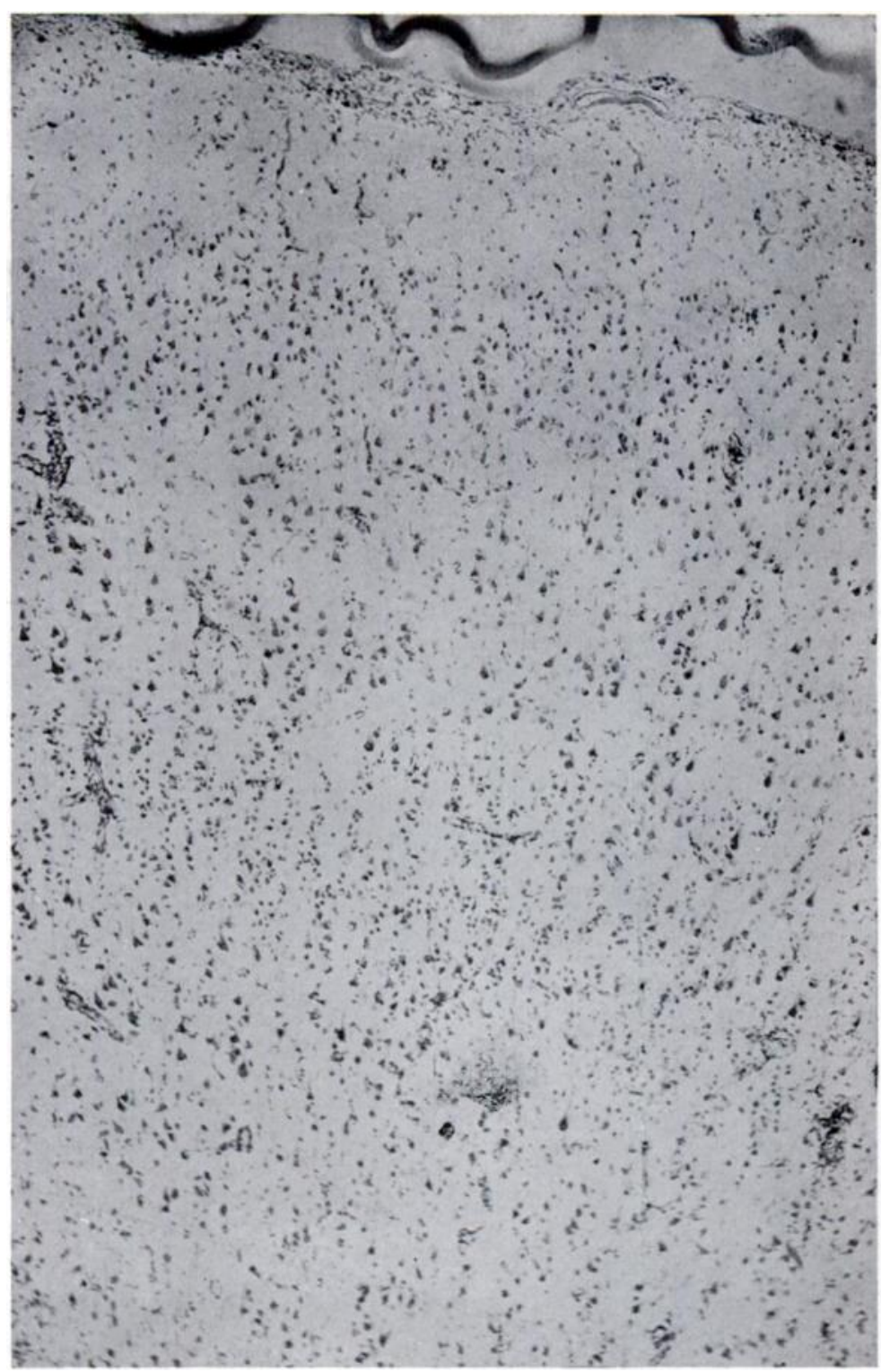

FiG. 15 . 
AMERICAN JOURNAL OF INSANITY, VOI. LXX, No. $4 . \quad$ PLATE XI.

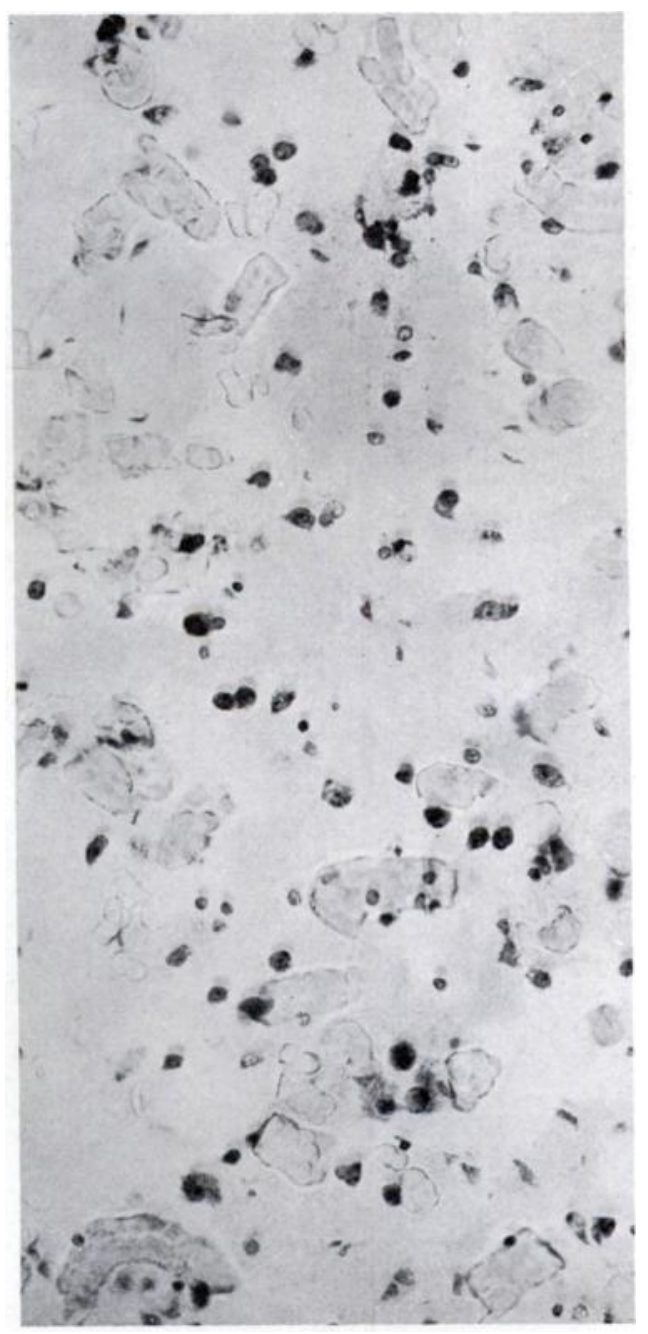

FIi. 16. 
AMERICAN JOURNAL OF INSANITY, VoI. LXX, No. 4. PLATE XII.

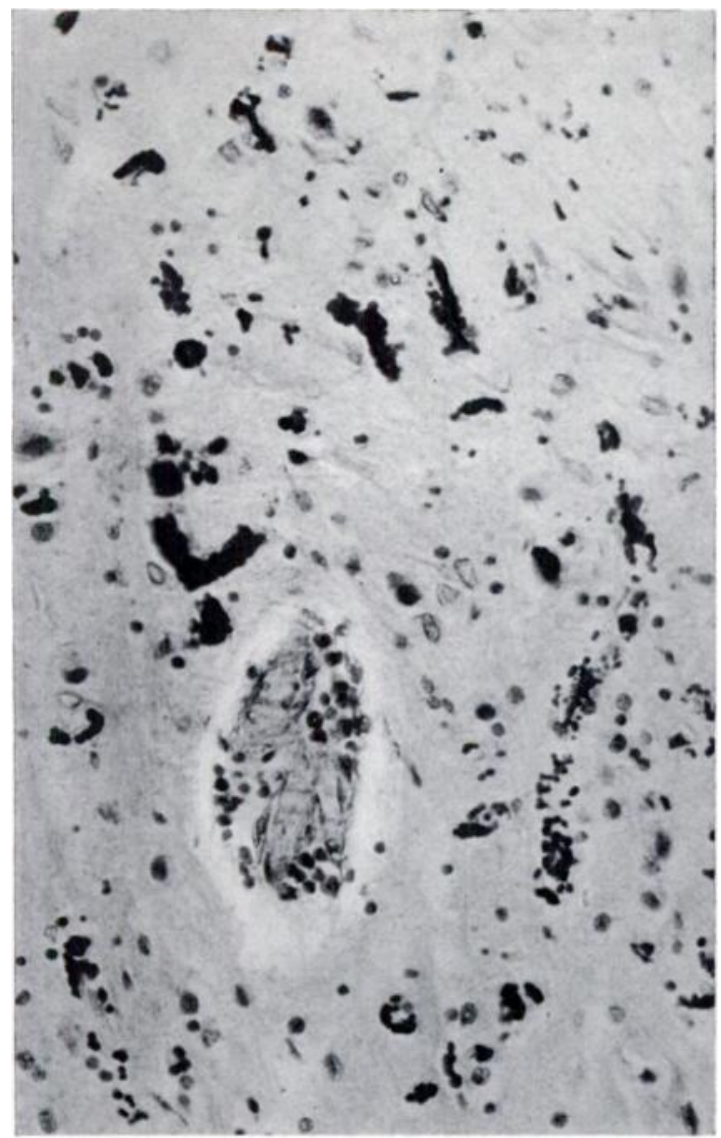

FIG. 17.

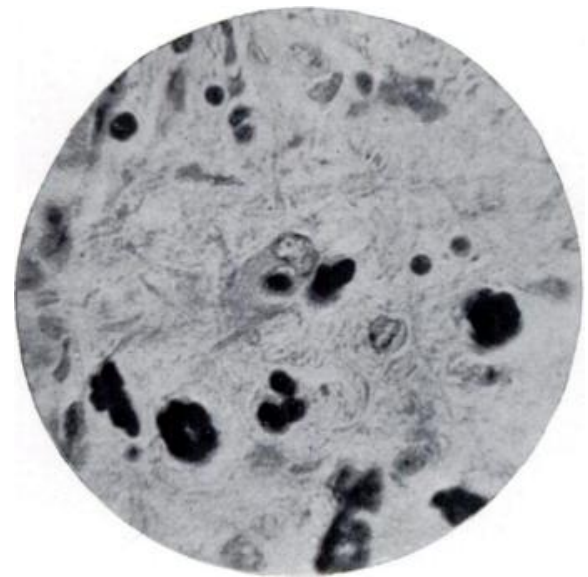

FIG. 18. 